PONTIFÍCIA UNIVERSIDADE CATÓLICA DO RIO DE JANEIRO

A moda da Farm

Um estudo sobre a percepção de marca de consumidores e não consumidores cariocas

Mariana Machado Wollny

Trabalho de Conclusão de Curso

CENTRO de CIÊNCIAS SOCIAIS - CCS

DEPARTAMENTO dE ADMINISTRAÇÃO

Graduação em Administração de Empresas 


\section{A moda da Farm \\ Um estudo sobre a percepção de marca de consumidores e não consumidores cariocas}

Trabalho de Conclusão de Curso

Trabalho de Conclusão de Curso, apresentado ao programa de graduação em Administração da PUC-Rio como requisito parcial para a obtenção do titulo de graduação em Administração.

Orientadora: Marina Frid

Rio de Janeiro, Dezembro de 2017. 


\section{Agradecimentos}

Dedico esse trabalho aos meus pais e os agradeço muito por tudo o que eles sempre me proporcionaram. Graças a eles eu sempre tive acesso aos melhores ensinos de estudos, fazendo que com que eu chegasse hoje aonde estou.

Gostaria de agradecer também minha irmã, meus avós, minha tia, minhas primas e meu padrasto pelo apoio durante toda minha trajetória profissional e também pessoal.

Agradeço também às minhas incansáveis e inseparáveis amigas, Camila e Marcella, por me acompanharem nesta etapa e fazerem com que a faculdade fosse maravilhosa.

Por fim, gostaria de agradecer à minha orientadora Marina Frid, por toda sua ajuda e orientação durante este período e a todos os profissionais da educação que contribuíram para hoje eu estar completando mais esta etapa em minha vida. 


\section{Resumo}

Wollny, Mariana. A Moda da Farm: um estudo sobre a percepção de marca de consumidoras e não consumidoras cariocas. (67p). Trabalho de Conclusão de Curso - Departamento de Administração. Pontifícia Universidade Católica do Rio de Janeiro.

Este trabalho possui como objetivo analisar a identidade idealizada pela Farm e a imagem da marca na visão dos consumidores e não consumidores para verificar se há uma lacuna entre estas percepções e se as mesmas podem acarretar algum impacto negativo à marca. Para se atingir o objetivo final deste estudo, identificam-se como objetivos intermediários a serem alcançados: apresentar a identidade da marca; conhecer as principais associações à marca estabelecidas por seus clientes; conhecer as principais associações à marca estabelecidas por não-clientes; verificar se as principais associações à marca feitas pelos não-clientes os desmotivam a comprar; verificar se as principais associações à marca feitas pelos seus não-clientes têm impacto negativo sobre a marca Farm.

Foi realizada uma revisão de literatura, incluindo artigos, livros e estudos acadêmicos. Para fazer a análise, foi realizado um questionário de forma quantitativa com uma amostra de 101 pessoas. Através da análise dos dados conclui-se que os consumidores e não consumidores possuem as mesmas percepções de imagem da Farm e que os aspectos negativos que ambos os públicos possuem podem impactar negativamente à marca através do marketing boca a boca.

Palavras-chave

Marketing Farm, consumo, percepção de marca. 


\section{Abstract}

Wollny,Mariana. Fashion at Farm: a study on the brand perception of consumers and non consumers from Rio de Janeiro (63p). Course conclusion paper- Business and Adminitration Department- Catholical Pontifical University of Rio de Janeiro.

This paper's objective is to analyze the identity envisioned by Farm and the brand image amongst consumers and non consumers in order to identify if there is a gap between these perceptions that could produce a negative impact on the brand. In order to reach the final objective the author has identified secondary objectives that will also be covered in this paper such as: present the brand identity; identify the main brand positioning amongst consumers and non consumers; evaluate if the brand positioning of non consumers is a barrier to buy Farm's products and if this brand positioning has a negative impact on Farm's brand.

In order to produce such analysis a bibliographical review was made and a quantitative questionnaire was applied to a sample of 101 persons. The author concludes that consumers and non consumers have the same perceptions about Farm's brand and that the negative aspects that both groups perceive could negatively impact the brand through mouth to mouth marketing.

Key-words

Marketing Farm, consumption, brand perceptions. 


\section{Sumário}

1. O TEMA E O PROBLEMA DE ESTUDO

1.1. INTRODUÇão AO TEMA E AO PROBLEMA DO ESTUDO

1.2. OBJETIVO PRINCIPAL E OBJETIVOS INTERMEDIÁRIOS DO ESTUDO 13

1.3. DeLIMITAÇão E FOCO Do ESTUdo

1.4. JUSTIFICATIVA E RELEVÂNCIA DO ESTUDO

$\begin{array}{lr}\text { 1.5. A MARCA FARM } & 14\end{array}$

2. REVISÃO DE LITERATURA

2.1. IMAGEM E IDENTIDADE DE MARCA 17

$\begin{array}{lr}\text { 2.2. BRAND EQUITY } & 18\end{array}$

2.2.1. LEALDADE À MARCA 20

2.2.2. O CONHECIMENTO DA MARCA 20

2.2.3. A QUALIDADE PERCEBIDA 21

2.2.4. ASSOCIAÇÕES À MARCA 22

2.3. ASSOCIAÇõES DE MARCAS

2.4. MARCAS SENSORIAIS E EXPERIENCIAIS

2.5. O CONSUMO PELA PERSPECTIVA DA CULTURA

3. MÉTODOS E PROCEDIMENTOS DE COLETA E DE ANÁLISE DE DADOS DO

ESTUDO $\quad 26$

3.1. TIPO DE PESQUISA REALIZADA 26

3.2. FONTE DE INFORMAÇÃO SELECIONADOS PARA COLETA DE DADOS NO ESTUDO 27

3.3. PROCEDIMENTOS E INSTRUMENTOS DE COLETA DE DADOS UTILIZADOS NO ESTUDO 27

3.4. FORMAS DE TRATAMENTO E ANÁLISE DOS DADOS COLETADOS PARA O ESTUDO 28

$\begin{array}{ll}\text { 3.5. LIMITAÇõES DO ESTUDO } & 28\end{array}$

4. APRESENTAĈ̣̃O E ANÁLISE DOS RESULTADOS $\quad 29$

4.1. DESCRIÇÃO DA AMOSTRA / DO PERFIL DOS ENTREVISTADOS 29

4.2. MOTIVAÇÃO E DESMOTIVAÇÃo / INTERESSES NA MARCA 33

4.2.1. CONSUMIDORES 33

4.2.2. NÃO CONSUMIDORES

4.3. ASSOCIAÇÕES À MARCA $\quad \mathbf{4 0}$

4.3.1. CONSUMIDORES 40

4.3.2. NÃO CONSUMIDORES 
5. CONCLUSÕES E RECOMENDAÇÕES PARA NOVOS ESTUDOS 51

6. REFERÊNCIA BIBLIOGRÁFICAS 53

APÊNDICE A 55

APÊNDICE B 63

APÊNDICE C 66 


\section{Lista de Figuras}

Figura 1: 0 Brand Equity 6

Figura 2: A Pirâmide Do Conhecimento 8

Figura 3: O Valor Das Associações De Marca 9 


\section{Lista de Gráficos}

Gráfico 1: Qual seu gênero? 18

Gráfico 2: Qual a sua faixa etária? 19

Gráfico 3: Qual a sua ocupação/profissão?

Gráfico 4: Onde você mora? 19

Gráfico 5: Qual sua faixa de renda familiar? $\quad 20$

Gráfico 6: Qual seu grau de escolaridade? $\quad 20$

Gráfico 7: Você já frequentou alguma loja da marca Farm? 21

Gráfico 8: Com qual frequencia voce vai a uma loja da marca? 21

Gráfico 9: O que te motica a entrar na loja? 22

Gráfico 10: Quando você compra na farm, você geralmente quer...

Gráfico 11: Existe algum aspecto que te desencoraja a comprar na Farm? Explique.

$\underline{55}$

Gráfico 12: Quais elementos você mais gosta nas lojas da Farm? 24

Gráfico 13: Quais elementos você não gosta nas lojas da Farm? 25

Gráfico 14: 0 que você considera que seja o diferencial da marca? 26

Gráfico 15: Quais aspectos te desencorajam a entrar na loja da Farm? 27

Gráfico 16: Quais elementos você mais gosta nas lojas da Farm? 28

Gráfico 17: Quais elementos você não gosta nas lojas da Farm? 29

Gráfico 18: Quais cores você associa à Farm? 30

Gráfico 19: Quais cidades você associa à marca? $\quad 30$

Gráfico 20: Quais situações você associa à Farm? 31

Gráfico 21: Quais emoções você associa à marca? 32

Gráfico 22: Qual estilo musical você associa à Farm? 32

Gráfico 23: Qual das opções abaixo mais se aproxima da imagem que você tem de um \begin{tabular}{ll} 
consumidor típico da Farm? & 33 \\
\hline
\end{tabular}

Gráfico 24: Você acha que a marca Farm dialoga com você? 34

Gráfico 25: Quais cores você associa à Farm? $\quad 35$

Gráfico 26: Quais cidades você associa à marca? $\quad 36$

Gráfico 27: Quais situações você associa à Farm? 37

Gráfico 28: Quais emoções você associa à marca? 37

Gráfico 29: Qual estilo musical você associa à Farm? 38

Gráfico 30: Qual das opções abaixo mais se aproxima da imagem que você tem de um consumidor típico da Farm? 
Lista de Tabelas

Tabela 1: Perfil dos não-consumidores da Farm 6

Tabela 2: Perfil dos consumidores da Farm que dizem que a marca não dialoga com eles 8 


\section{O tema e o problema de estudo}

\subsection{Introdução ao tema e ao problema do estudo}

O presente trabalho estuda as percepções sobre a marca da Farm de consumidores e não-consumidores cariocas. O objetivo é analisar a identidade idealizada pela Farm e a imagem da marca na visão dos consumidores e não consumidores para verificar se há uma lacuna entre estas percepções e se as mesmas podem acarretar algum impacto negativo à marca.

A Farm surgiu em 1997, em um estande na Babilônia Feira Hype dos sócios Kátia Barros e Marcello Bastos. Como a marca fez muito sucesso, em 1999 abriram sua primeira loja e, posteriormente, uma rede de lojas, conquistando cidades, estados e até outros países. Neste ano de 2017, as roupas e os acessórios da marca foram vendidos em uma pop-up store montada no Festival Coachella, na Califórnia, EUA.

Em uma entrevista à Revista Estilo (2012), Kátia definiu o perfil de clientes da Farm como "meninas jovens, entre 20 e 25 anos, moradoras da Zona Sul do Rio de Janeiro, estudantes da PUC, que se interessam por moda e vão à praia no Leblon e em Ipanema". Mas que "esse perfil retrata o espírito de leveza do carioca no dia a dia".

Segundo o site da loja, a Farm tornou-se a marca da garota carioca: "menos salto alto e mais pé na areia, menos maquiagem e mais bronzeado, menos chapinha e mais cabelo secando ao vento depois de um mergulho no mar, menos espelho e mais olho no olho, menos relógio e mais nosso próprio tempo". A Farm se diferencia pelas suas estampas coloridas, alegres e florais, que são suas marcas registradas.

Portanto, o público que consome as roupas da Farm seria limitado, sobretudo, às jovens adultas que moram na zona sul do Rio de Janeiro ou frequentam esses bairros para atividades de estudo e lazer. Sendo assim, qual é a percepção de marca dos consumidores e dos não consumidores da Farm? 


\subsection{Objetivo principal e objetivos intermediários do estudo}

Este trabalho tem como objetivo analisar a identidade idealizada pela Farm e a imagem da marca na visão dos consumidores e não consumidores para verificar se há uma lacuna entre estas percepções e se as mesmas podem acarretar algum impacto negativo à marca.

Para se atingir o objetivo final deste estudo, identificam-se como objetivos intermediários a serem alcançados:

Apresentar a identidade da marca

Conhecer os principais elementos associados à marca por seus clientes

Conhecer os principais elementos associados à marca por não-clientes

> Verificar se as principais associações à marca feitas pelos não-clientes os desmotivam a comprar

> Verificar se as principais associações à marca feitas pelos seus nãoclientes têm impacto negativo sobre a marca Farm.

\subsection{Delimitação e foco do estudo}

Este estudo aborda especificamente a análise da percepção da marca. A pesquisa foi feita por meio de um questionário respondido por meio digital por 101 pessoas. A maior parte dos respondentes são moradores da zona sul do Rio de Janeiro e mulheres com faixa etária entre 18 e 35 anos. Esta análise é interessante para a Farm ter um feedback de suas diretrizes escolhidas e analisar as consequências das mesmas para solucioná-las ou reforçá-las, agregando assim, valor à marca.

O estudo busca verificar possíveis fatores que desmotivam ou impedem o consumo da marca entre não-clientes. Esses fatores podem ter um impacto negativo na percepção dos consumidores e gerar uma imagem indesejada pela Farm, que eventualmente se propaga pelo boca a boca. 


\subsection{Justificativa e relevância do estudo}

Esse estudo pode produzir informações interessantes para a marca, que seria capaz de possuir, assim, um feedback de suas escolhas e tomar as devidas providências, solucionando-as ou reforçando-as. Se a Farm faz determinadas escolhas, e possui um feedback negativo, ela pode, assim, solucionar isto para atrair potenciais clientes; ou se possuir um feedback positivo, pode investir mais nisto, para continuar com a fidelidade de seus consumidores.

Os resultados a serem alcançados também podem ser aproveitáveis pela concorrência, pois se forem negativos, os mesmos podem tirar proveito e investir em suas marcas. Por exemplo, se a Farm tem determinadas diretrizes que não agradam os consumidores, a concorrência poderá fazer justamente o inverso para atrair esses potenciais clientes.

\subsection{A Marca Farm}

A marca carioca Farm possui como sócios a estilista Kátia Barros e seu amigo Marcello Bastos. É uma loja de roupas femininas, despojadas, coloridas e praianas, com tendência hippie-romântica, focada em meninas universitárias e descoladas (TEAM RP, 2010). Segundo a apresentação fornecida pela empresa, a Farm possui um estilo de vida carioca, que é desejado mundialmente. A organização se considera o sinônimo de moda carioca. Possui um preço competitivo, novidades todos os dias nas lojas e é referência em estampa. Detém também parcerias, acordos de licenciamento e produtos co-branded com a Disney e com as Havaianas, por exemplo.

Segundo a Revista Vogue (2015), Kátia é carioca, moradora de Ipanema e cresceu nesse ambiente praiano e descolado. Se formou em Ciências Contábeis pela UFRJ, e após dois anos de sua graduação, trabalhando na empresa Ernst \& Young, viu que não era essa profissão que queria seguir. Sendo assim, em 1996, aceitou o convite de seu pai e de Marcello, sócios em uma empresa de distribuição de jornais argentinos no Brasil, para se juntar a eles em uma abertura de uma franquia de marca de roupas paulistas. $O$ empreendimento não deu certo, e em 1997, Kátia e Marcello começaram a vender seus produtos seis modelos de uma peça que se tornou febre na cidade, o body - na Babilônia Feira Hype. Essa feira reunia pequenos estandes de marcas alternativas e 
jovens estilistas, e o da Farm fez um grande sucesso, batendo recorde de vendas.

Ainda segundo a revista, Kátia decidiu cursar moda para aprender o lado mais técnico da criação, e suas peças foram inspiradas no ambiente em que cresceu: com muitas estampas, coloridas, despojadas, descoladas e praianas.

Segundo o site Team Rp (2010), em 1999, Kátia e Marcello abriram sua primeira loja no Posto 6, em Copacabana. Em 2001, abriram lojas no Fórum de Ipanema e no Shopping Downtown, na Barra da Tijuca. A expectativa de vendas naquele fim de ano era de 15 mil peças. Porém, as vendas foram quase três vezes mais: venderam 42 mil peças. Desde então, os sócios abriram lojas em todo o Rio de Janeiro e no Brasil inteiro. São cerca de 68 lojas espalhadas: Gávea, Leblon, Búzios, Belo Horizonte, Niterói, Brasília, São Paulo, Goiânia, Salvador, Porto Alegre, Curitiba, entre outros. Na maioria das lojas, as vendas superam as expectativas.

Ainda segundo o site, em 2005 a Farm foi convidada para ter um estande exclusivo de 25 m2, durante o verão europeu, na Galeries Lafayette, em Paris.

Em 2008 construíram a sede da marca em São Cristóvão, no Rio de Janeiro, com cerca de $7.000 \mathrm{~m} 2$ e com verde por todos os lados. Na fábrica é possível encontrar salão de beleza, aulas de ioga, sala de reunião com paredes de vidro no meio da mata e oficinas de percussão. Neste mesmo ano também inauguraram sua marca infantil, a Fábula (REVISTA VOGUE, 2015).

Segundo a apresentação fornecida pela empresa, em 2009, possuíam 50 mil pageviews por dia em seu site online, no "adoro!" e 25 mil seguidores no twitter. Também em 2009, a moda Farm seguiu o viés da decoração: tinham sofás, almofadas, quadros, com as estampas da marca.

Em 2010, os sócios venderam um terço da marca para Roberto e Claudia Jatahy, fundadores de outra grande marca de roupas carioca, a Animale, e desde então o crescimento da Farm foi de 35\% ao ano. Neste ano também receberam o Global Fashion Awards, um prêmio na categoria experiência de compra (O NEGÓCIO DO VAREJO, 2014).

Segundo a apresentação fornecida pela empresa, em 2011 foi iniciado "o adoro", a loja virtual, o lookbook, a galeria, a rádio e as mídias sociais, aumentando o contato com seus clientes.

Já em 2014 todas as grifes, dos quatro sócios, passaram a fazer parte de um único grupo: o Grupo Soma de Moda. Esse grupo é composto pelas marcas Farm (dona de 25\%), Animale, A.Brand, FYI, Fábula, e mais recentemente Foxton, única marca masculina do grupo (REVISTA VOGUE, 2015). 
Ainda segundo a revista, em 2015 a organização possuía cerca de 1.800 funcionários e faturou cerca de $\mathrm{R} \$ 410$ milhões.

E finalmente, atualmente em 2017, a Farm possui cerca de 2 milhões de seguidores no Facebook (FACEBOOK FARM, 2017). 


\section{Revisão de literatura}

Neste capítulo são apresentados e discutidos aspectos conceituais e estudos relacionados ao tema e estudo em investigação e que servirão de base para a análise realizada.

Esta seção está dividida em cinco partes, que abordam, respectivamente, a imagem e identidade de marca, a construção de marcas, as associações de marcas, as marcas sensoriais e experienciais, e o consumo para contextualizar o problema de estudo.

\subsection{Imagem e Identidade de marca}

"Imagem de marca pode ser definida como o conjunto de atributos e associações que os consumidores reconhecem e conectam com o nome de marca" (PINHO, 1996, p. 50). Para Aaker (1998), uma imagem de marca é um conjunto de associações organizadas de alguma forma significativa.

Segundo Pinho (1996), para formar uma imagem de marca, há ainda a contribuição da imagem da empresa, da imagem do usuário e da imagem do produto ou serviço em si. Ainda conforme o autor, as associações que formam a imagem de marca podem ser tangíveis (hard) ou intangíveis (soft). As tangíveis são os atributos funcionais, como a performance do produto, preço, garantia, serviços e tecnologia. E as intangíveis são atributos como masculinidade, feminilidade, entusiasmo, confiança, diversão, eficiência. Esses causam maior impacto no comportamento do consumidor, garantindo um maior reconhecimento das diferenças entre as marcas mais importantes de uma categoria. A imagem de marca é construída também através de, por exemplo, informações veiculadas pelos meios de comunicação, experiências no uso do produto, embalagem, identidade da empresa, promoção de vendas, propaganda e publicidade. Esta última é a mais importante, pois é uma atividade de comunicação, que se destaca tanto pelo elevado grau de controle que permite sobre as mensagens, quanto pelo poder de penetração e convencimento junto aos consumidores (PINHO, 1996). 
Já "a identidade da marca é um conjunto exclusivo de associações com a marca que seus gestores ambicionam criar ou manter. Essas associações representam aquilo que a marca pretende realizar e implicam uma promessa aos clientes, feita pelos membros da organização" (AAKER, 2007, p. 73). Pode também ajudar a estabelecer um relacionamento entre a marca e o cliente, através de uma proposta de valor envolvendo benefícios funcionais, emocionais e de auto-expressão.

\subsection{Brand Equity}

"O brand equity é um conjunto de ativos e passivos ligados a uma marca, seu nome e seu símbolo, que se somam ou se subtraem do valor proporcionado por um produto ou serviço para uma empresa e/ou para os consumidores dela" (AAKER, 1998, p. 16). Segundo Aaker (1998), o brand equity proporciona valor ao consumidor através do aumento da sua interpretação/processamento de informação, maior confiança na decisão de compra e satisfação de uso. E à empresa, proporciona valor através do aumento da eficiência e eficácia dos programas de marketing, lealdade à marca, preços/margens, extensões da marca, incremento com o trade, e vantagem competitiva.

Ainda segundo Aaker (1998), o valor de uma marca pode ser percebido através da lealdade à marca, do conhecimento da marca, da qualidade percebida, das associações à marca em acréscimo à qualidade percebida, e de outros ativos do proprietário da marca (patentes, trademarks, relações com os canais de distribuição, etc) conforme mostra a figura a seguir: 
Figura 1: $O$ Brand equity

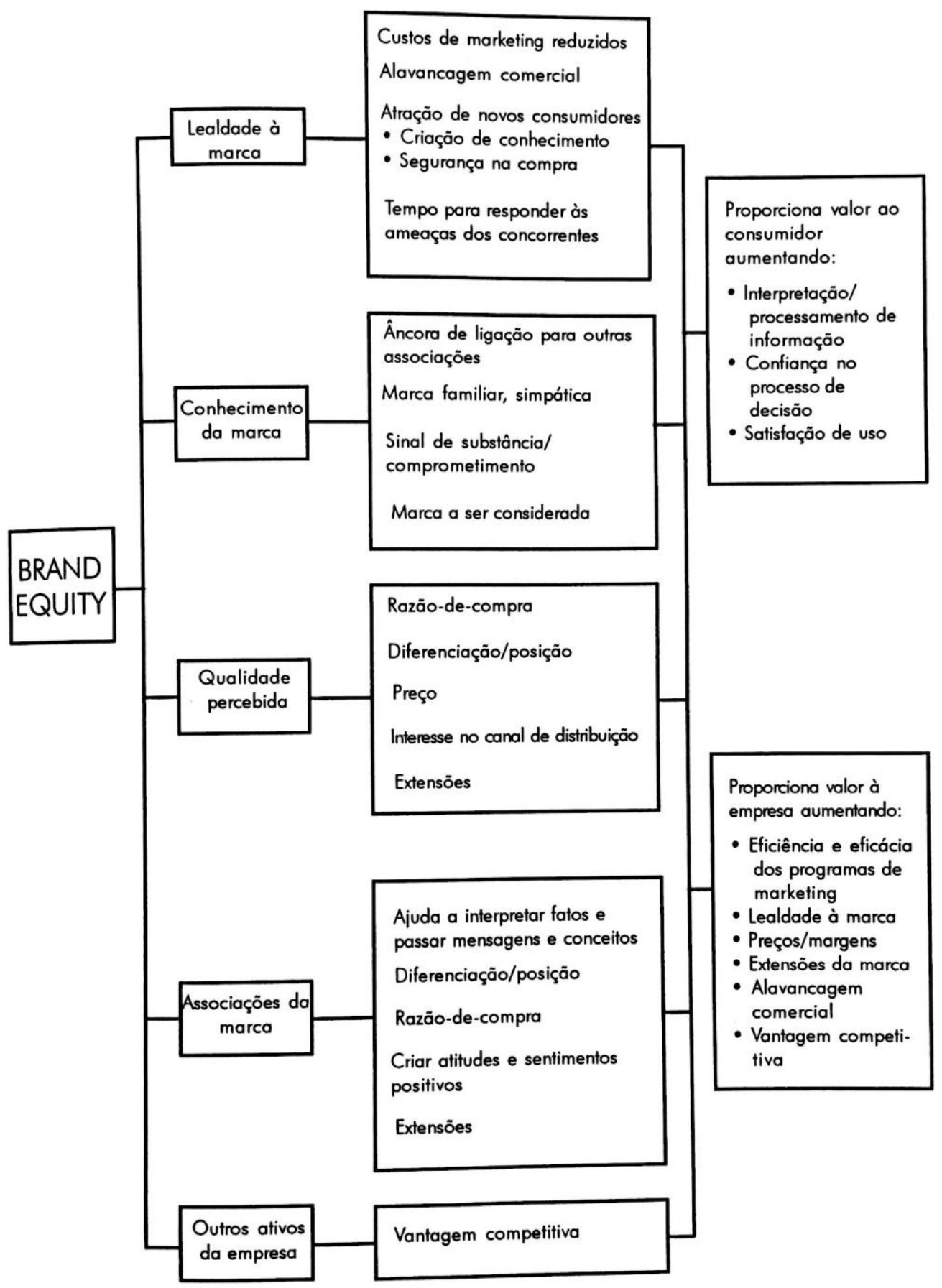

Fonte: Aaker, 1998, pág. 284 


\subsubsection{Lealdade à Marca}

Segundo Aaker (1998), a lealdade dos consumidores à marca é frequentemente o mais importante do brand equity e só existe após eles terem experimentado o produto ou serviço. Ainda conforme o autor, a lealdade à marca é o que mede a ligação do consumidor com a marca. Se os clientes compram sem considerar o nome da marca, se importando apenas com as características, preço e conveniência, provavelmente há pouco brand equity. $\mathrm{E}$ se, continuam a comprar na marca mesmo que exista concorrentes com características superiores, preço e conveniência, existe valor na própria marca (AAKER, 1998).

De acordo com o autor, quanto maior a lealdade do consumidor à marca, menor a vulnerabilidade da mesma no mercado, desencorajando assim, os concorrentes a investirem recursos.

"É um indicador do brand equity claramente ligado aos lucros futuros, uma vez que a lealdade à marca se traduz diretamente em vendas futuras." (AAKER, 1998, p. 41).

Ainda segundo Aaker (1998), há cinco níveis de lealdade à marca, que mostram que um cliente pode ser fiel ou não por diversos motivos:

$1^{\circ}$ : Não leal à marca - É sensível a preço indiferente à marcas

$2^{\circ}$ : Satisfeito - Compra sempre sem razão para mudar

$3^{\circ}$ : Satisfeito - Mas com medo dos custos de mudança

$4^{\circ}$ : Gosta da marca - considera-a amiga

$5^{\circ}$ : Comprador - Comprometido

\subsubsection{O Conhecimento da Marca}

"O conhecimento da marca é a capacidade que um comprador potencial tem de reconhecer ou de se recordar de uma marca como integrante de uma certa categoria de produtos. Isto pressupõe um elo entre a classe do produto e a marca." (AAKER, 1998, p. 64).

O conhecimento da marca envolve, também, um intervalo de sentimentos contínuo, de que a marca seja reconhecida, até a crença de que ela é a única na classe de produtos (AAKER, 1998). Esse intervalo é retratado por três níveis muito diferentes de conhecimento da marca, como mostra a figura abaixo: o 
reconhecimento da marca (nível mais baixo), a lembrança da marca (nível intermediário), e o Top of Mind (nível mais alto). "O papel do conhecimento da marca no brand equity dependerá tanto do contexto como do nível de conhecimento atingido." (AAKER, 1998, p. 65).

Figura 2: A Pirâmide do Conhecimento

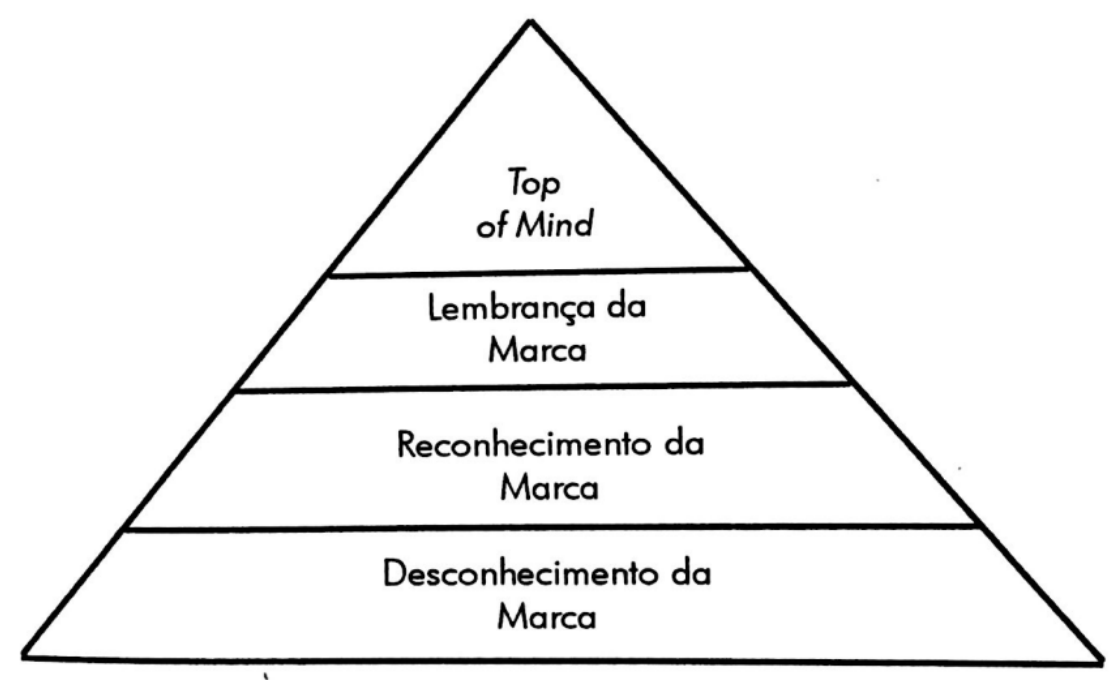

Fonte: Aaker, 1998, pág. 65

Para Aaker (1998), o nível mais baixo, o "reconhecimento da marca", se baseia em um teste de recall estimulado, onde são citados alguns nomes de marcas para o consumidor lembrar de qual ele já ouviu falar anteriormente. Este estágio é importante para o comprador que escolhe a marca no ponto de venda.

Ainda segundo o autor, a "lembrança da marca" não necessita do estímulo utilizado como o nível anterior, e a recordação sem ajuda está associada com uma posição mais forte da marca. De acordo com Aaker (1998), a primeira marca mencionada numa pesquisa de recall sem estímulo alcança a classificação de "Top of Mind".

\subsubsection{A qualidade percebida}

"A qualidade percebida pode ser definida como o conhecimento que 0 consumidor tem da qualidade geral ou superioridade de um produto ou serviço pretendido, em relação a alternativas" (AAKER, 1998, p. 88). Ou seja, a qualidade percebida é o conhecimento dos consumidores. 
Ainda segundo Aaker (1998), qualidade percebida é diferente de qualidade real ou objetiva, que é o quanto o produto ou serviço agrega com serviço superior; de qualidade baseada no produto, que é a natureza e quantidade dos ingredientes, características ou serviços envolvidos; e de qualidade de fabricação, que é a conformidade com as especificações, a meta de "defeito zero".

\subsubsection{Associações à marca}

"Uma associação de marca é algo "ligado" a uma imagem na memória" (AAKER, 1998, p. 114). Segundo Aaker (1998), as associações criam valores para a empresa e seus consumidores de algumas maneiras: ajudam a processar/encontrar a informação; diferenciam a marca; geram uma reação para comprar, criam atitudes/feelings positivos, e proporcionam uma base para extensões, como mostra a figura abaixo:

\section{Figura 3: O Valor das Associações de Marca}

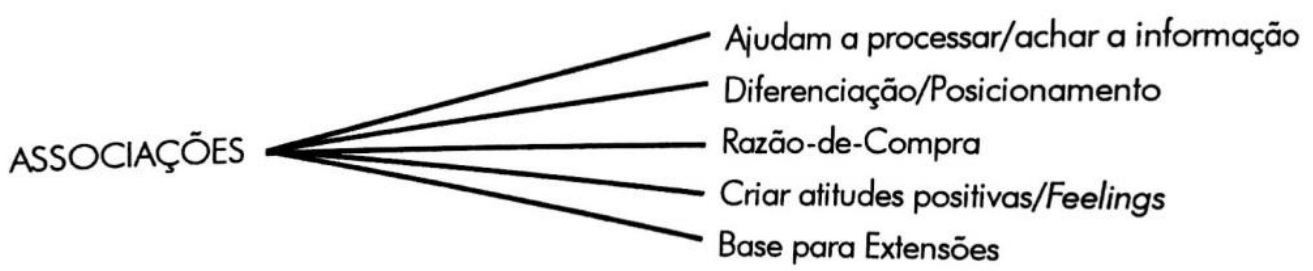

Fonte: Aaker, 1998, pág. 116

No item "ajudam a processar/achar a informação", segundo Aaker (1998), as associações resumem um conjunto de fatos e especificações, que, de outra forma, seria difícil para o consumidor processar e acessar, e caro para a empresa comunicar. Uma associação pode criar informações para o consumidor, possibilitando-o um meio de assimilação.

O item "diferenciação/posicionamento" é caracterizado por "uma associação que pode proporcionar uma importante base para a diferenciação" (AAKER, 1998, p. 117). As associações do nome da marca podem desempenhar um papel crítico na separação de uma marca da outra, e uma associação diferenciadora pode ser uma vantagem competitiva chave. 
No item "razão-de-compra", "muitas associações da marca envolvem atributos de produtos ou benefícios aos consumidores que propiciam uma razão específica para comprar e usar a marca" (Aaker, 1998, p. 117). Segundo o autor, pela credibilidade e confiança da marca, algumas associações influenciam a decisão de compra.

Já em "criar atitudes/sentimentos positivos", segundo Aaker (1998), algumas associações são respeitadas e estimulam sentimentos positivos, que se transferem à marca. "As associações e seus sentimentos correlatos ficam, então, ligados à marca" (AAKER, 1998, p. 118), e algumas associações criam sentimentos positivos conforme o uso.

Por último, no item "base para extensões", "uma associação pode proporcionar a base de uma extensão, criando um senso de adequação entre o nome da marca e um ovo produto, ou dando uma razão-de-compra da extensão" (AAKER, 1998, p. 118).

\subsection{Associações de marcas}

Segundo Aaker (1998), uma associação da marca é qualquer coisa ligada à marca que venha na mente. A posição da marca baseia-se nas suas associações e em como elas se diferenciam da concorrência. "Uma associação pode afetar o processamento e a recordação de informação, proporcionar um ponto de diferenciação e uma razão-de-compra, criar atitudes e sentimentos positivos, e servir como base para extensões" (AAKER, 1998, p. 286).

Para Aaker (1998), o posicionamento está relacionado ao conceito de imagem e associação, salvo quando implica um quadro de referência no qual está a concorrência.

Ainda conforme Aaker (1998), uma associação possui um grau de força. Uma ligação com uma marca se torna mais forte quando é baseada em diversas experiências a comunicações e quando é apoiada por uma rede de outras associações. "Uma marca bem-posicionada terá uma atraente posição competitiva, suportada por fortes associações" (AAKER, 1998, p. 115).

Segundo Pinho (1996), as associações contribuem para adicionar valor à marca, diferenciando-a dos seus concorrentes e estimulando emoções e sentimentos. "Muitas vezes, as associações podem fundamentar as decisões de compra, já que envolvem atributos do produto ou benefícios ao consumidor que 
proporcionam uma razão específica para a compra ou o uso do produto" (PINHO, 1996, p. 99).

\subsection{Marcas Sensoriais e Experienciais}

As marcas sensoriais, que também podem ser chamadas de "marketing sensorial" caracterizam-se por "empresas que depositam especial atenção ao impacto das sensações em nossas experiências com o produto" (SOLOMON, 2011, p. 84). Os profissionais de marketing utilizam os sistemas sensoriais para criar vantagem competitiva: a visão, o olfato, a audição, o tato e o paladar. Uma marca ou um ambiente são associados aos estímulos provocados através de suas cores, cheiros, som, etc.

Ainda segundo Solomon (2011), esses profissionais apostam muito nos elementos visuais em publicidade e no design de lojas e embalagens, através da cor, do tamanho e do estilo do produto.

Os odores podem criar uma sensação de tranquilidade ou estimular emoções, como também podem trazer recordações ou aliviar o estresse. Conforme os cientistas vão descobrindo os efeitos que o olfato pode causar sobre o comportamento, os profissionais de marketing criam diversas maneiras de explorar tais ligações: como, por exemplo, a audição, o som, podem afetar os sentimentos e comportamentos das pessoas (SOLOMON, 2011).

Para Solomon (2011), as sensações que atingem a pele, como por exemplo, uma agradável massagem ou a ardência de um vento de inverno, estimulam ou relaxam. Já o toque pode influenciar as interações de vendas.

E por último, o paladar, segundo Solomon (2011), contribui para as experiências que temos com muitos produtos. Empresas especializadas, chamadas também de "casas de sabor", criam novas misturas para agradar ao paladar, que muda constantemente, dos consumidores.

As marcas experienciais, que também podem ser chamadas de "marketing experiencial", criam diferentes tipos de experiências para os clientes. Está presente em uma variedade de mercados e indústrias, que o utilizam para, por exemplo, desenvolver novos produtos, melhorar as relações de vendas e selecionar parceiros de negócios (SCHMITT, 1999).

Para Schmitt (1999), esses tipos de experiências criadas podem ser chamadas de "módulos experienciais estratégicos" (SEMs em inglês). Cada um desses módulos possuem estruturas distintas e princípios de marketing. Os 
SEMs incluem experiências sensoriais, experiências afetivas, experiências cognitivas criativas, experiências físicas e experiências de identidade social resultantes da relação com um grupo ou cultura de referência.

\section{5. $O$ consumo pela perspectiva da cultura}

Segundo McCraken (2003), o consumo deve ser entendido como um fenômeno da cultura. Os bens são plenos de significados culturais e existe uma coerência entre os mesmos que possibilita certas combinações e inibe outras. McCracken (2003) sugere o conceito de "unidade Diderot" para explicar como bens de consumo podem se complementar ou se repelir, dependendo se o conjunto tem ou não consistência cultural interna. Ao obter um bem que não combina com os significados dos que já possuía, o consumidor pode se sentir impelido a adquirir outros que casem melhor com sua nova aquisição, ou, desistir do item para recompor a harmonia do conjunto.

McCraken (2003) chama esse processo de aproximação e afastamento entre os bens de "efeito Diderot". A referência ao filósofo Denis Diderot se deve a um ensaio publicado pelo mesmo, no qual relata a transformação ocorrida em seu gabinete por causa de um robe escarlate que ganhara de presente. Ao desistir do seu velho roupão e aceitar o novo, Diderot se sentiu levado a renovar paulatinamente todos os demais itens do quarto para que tudo combinasse com a nova vestimenta. As "unidades Diderot" ajudam a compreender como estilos de vida são formulados a partir da exigência de complementaridade entre os bens que se impõe no universo do consumo (Pereira e Barros, 2012).

A partir da perspectiva da antropologia do consumo, Pereira e Barros (2012) examinam o caso da Farm e as associações que constroem a imagem da marca como como um símbolo do Rio de Janeiro. Como examinam as autoras, a marca combina determinadas "unidades" que aludem à cidade e compõem um estilo de vida carioca. Isto é, o discurso da Farm tanto absorve quanto reforça valores e ideais vinculados ao Rio de Janeiro e ao "jeito carioca de ser". Dessa forma, a marca busca dialogar com um determinado perfil de consumidoras jovens. 


\section{Métodos e procedimentos de coleta e de análise de dados do estudo}

Este capítulo pretende informar sobre as diversas decisões a cerca da forma como este estudo foi realizado e por isto está dividido em cinco seções que descrevem, respectivamente, as etapas de coleta de dados do estudo realizado, sobre as fontes de informação selecionadas para coleta de informações desta pesquisa. Na sequência, é abordado sobre os processos e instrumentos de coleta de dados realizados em cada etapa, com respectivas justificativas, as formas escolhidas para tratar e analisar os dados coletados e, por fim, as possíveis repercussões que as decisões sobre como realizar o estudo impuseram aos resultados assim obtidos.

\subsection{Tipo de pesquisa realizada}

Para realizar esse trabalho, foi desempenhado uma pesquisa quantitativa. Esse tipo de pesquisa "pode ser definida como uma pesquisa de marketing que aborda os objetivos da pesquisa por meio de avaliações empíricas que envolvem medição e análise numérica" (ZIKMUND E BABIN, 2011, p. 112). Este método foi escolhido pela sua eficiência em analisar a percepção de imagem dos consumidores perante a Farm.

Uma pesquisa descritiva é aquela que "descreve características de objetos, pessoas, grupos, organizações ou ambientes, ou seja, descreve ações do mercado" (ZIKMUND E BABIN, 2011, p. 52). Além de, muitas vezes, ajudar a descrever os segmentos de mercado. Sendo assim, pode-se dizer que este tipo de pesquisa também foi utilizado no trabalho, pois busca analisar os hábitos dos entrevistados. 


\subsection{Fonte de informação selecionados para coleta de dados no estudo}

Nesse estudo houve coleta de dados primários através de um questionário, com o objetivo de verificar o perfil dos consumidores e dos não consumidores da marca, quais associações eles fazem à Farm, e o que os desagradam nela. $O$ questionário é um instrumento de captura de dados por meio de questões escritas ou orais (MALHOTRA, 2006).

Foi utilizado também coleta de dados secundários, que são dados que já foram reunidos e registrados por outra pessoa antes do projeto atual (ZIKMUND E BABIN, 2011). Além dos dados primários e secundários, foi usado também livros de marketing, artigos, publicações e pesquisas, através de sites da internet.

Os elementos de interesse durante a pesquisa foram o perfil do consumidor e do não consumidor da Farm e a percepção de imagem deles perante à marca, com base nos critérios de Aaker (1998; 2007), Pinho (1996) e Schmitt (1999). O consumidor ideal da Farm é aquele com o perfil que a marca estipulou: meninas universitárias, jovens, cariocas, praianas, e o consumidor real é aquele que realmente se identifica com a marca, que compra os produtos, independente se encaixa-se no perfil estipulado pela marca ou não. Já os não consumidores são aqueles que não se identificam com a marca, não gostam dos produtos, das estampas, do atendimento ou de algum outro fator. A amostra foi composta por 101 pessoas, incluindo os clientes da marca e os não-clientes.

\subsection{Procedimentos e instrumentos de coleta de dados utilizados no estudo}

A pesquisa foi realizada em outubro de 2017, com 101 respondentes e foi estruturada em três partes: o perfil do consumidor, o brand equity da Farm e as associações do consumidor com a marca. A segunda e terceira partes foram analisadas baseadas nos conceitos de Aaker (1998; 2007), Pinho (1996) e Schmitt (1999).

A coleta de dados foi realizada através de uma pesquisa no software Qualtrics, e enviada pelo aplicativo de conversas instantâneas WhatsApp e pelo Facebook. 
O questionário possui perguntas fechadas e abertas, nos quais coloca-se algum problema e pede-se que os entrevistados respondam com suas próprias palavras (ZIKMUND e BABIN, 2011). Esse tipo de pergunta aberta possui como objetivo não influenciar o entrevistado. Possui também perguntas da lista, que permitem que o entrevistado forneça mais de uma resposta para uma única pergunta (ZIKMUND e BABIN, 2011). Além destas, houveram perguntas de resposta única, onde o entrevistado escolheu uma única resposta dentre várias.

\subsection{Formas de tratamento e análise dos dados coletados para o estudo}

Um software de planilhas eletrônicas Microsoft Office Excel 2013 foi utilizado para revelar através de dados tabulados e interpretados em gráficos, as respostas dos entrevistados. Foi realizado também uma análise descritiva das estatísticas encontradas no questionário e a relação entre elas.

\subsection{Limitações do Estudo}

Como a pesquisa atinge um pequeno número de entrevistados, pode haver uma generalização dos resultados. Isso se deve pelo fato dos respondentes possuírem o mesmo nível social, havendo assim, provavelmente, um grau semelhante de afinidade. 


\section{Apresentação e Análise dos Resultados}

Este capítulo apresenta a análise dos dados coletados durante as entrevistas realizadas. A análise foi dividida em quatro subitens, com o objetivo que entender a percepção dos consumidores e não consumidores da marca: a marca; descrição da amostra/perfil dos entrevistados; motivação e desmotivação/interesses na marca; e associações à marca.

Foram entrevistadas 101 pessoas, onde os consumidores responderam 21 questões e o não consumidores responderam 17 questões.

\subsection{Descrição da amostra / do perfil dos entrevistados}

A pesquisa investigou o perfil dos entrevistados, seu gênero, sua faixa etária, sua ocupação/profissão, aonde mora, sua faixa de renda familiar, seu grau de escolaridade e se já frequentou a Farm.

De acordo com as perguntas sobre o gênero dos 101 respondentes, foi concluído que $84,16 \%$ destes são do sexo feminino, sendo assim a maioria, e apenas $15,84 \%$ do sexo masculino, como mostra o gráfico 1. Além disso, podese concluir que mais de $90 \%$ da amostra são representados por jovens com idades entre 18 e 35 anos, conforme o gráfico 2. É possível dizer também, que há poucos respondentes acima de 46 anos, representando apenas 6,93\% da amostra, pelo fato da coleta de dados ter sido realizada por pessoas mais próximas e de fácil acesso.

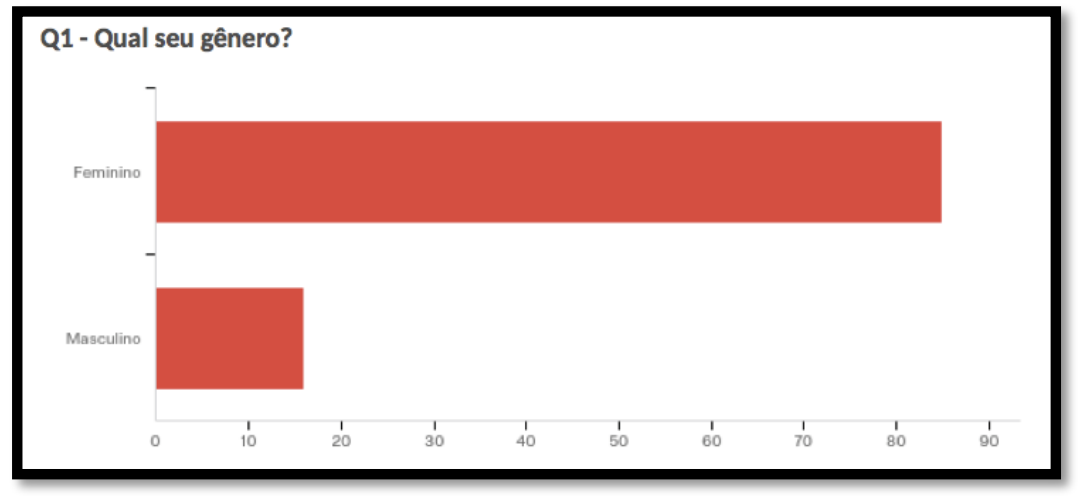




\section{Gráfico 1: Qual seu gênero?}

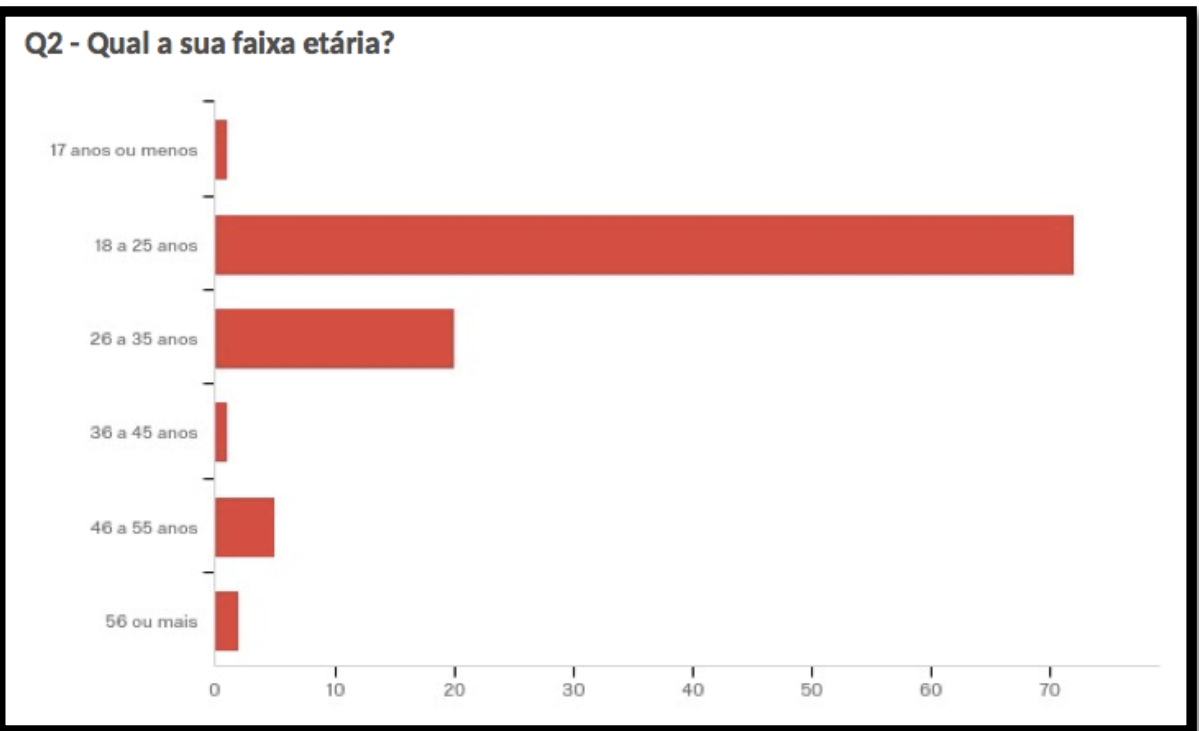

\section{Gráfico 2: Qual a sua faixa etária?}

Como a maior parte dos entrevistados são jovens, 64\% deles disseram ser estudantes ou estagiários, segundo o gráfico 3 (Apêndice B). Conforme o gráfico abaixo, 95,05\% dos respondentes moram no estado do Rio de Janeiro, sendo sua maioria na Zona Sul carioca, representado por $74,26 \%$, da amostra. Os entrevistados que moram fora do Rio de Janeiro representam por apenas 4,95\%, residentes de Salvador (Bahia), Londres (Inglaterra), Minas Gerais, São Paulo e Fortaleza (Ceará).

Zona Norte do

Zona Norte do Rio
de Janeiro

Zona Oeste do Rio

de Janeiro

Fora do Rio de
Janeiro

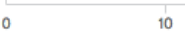

20

30

40

50

60

80

Gráfico 4: Onde você mora? 
A maior parte dos respondentes são das classes sociais $A$ e $B$, representando $81,18 \%$ da amostra e estão cursando ou já completaram o Ensino Superior $(85,15 \%)$.

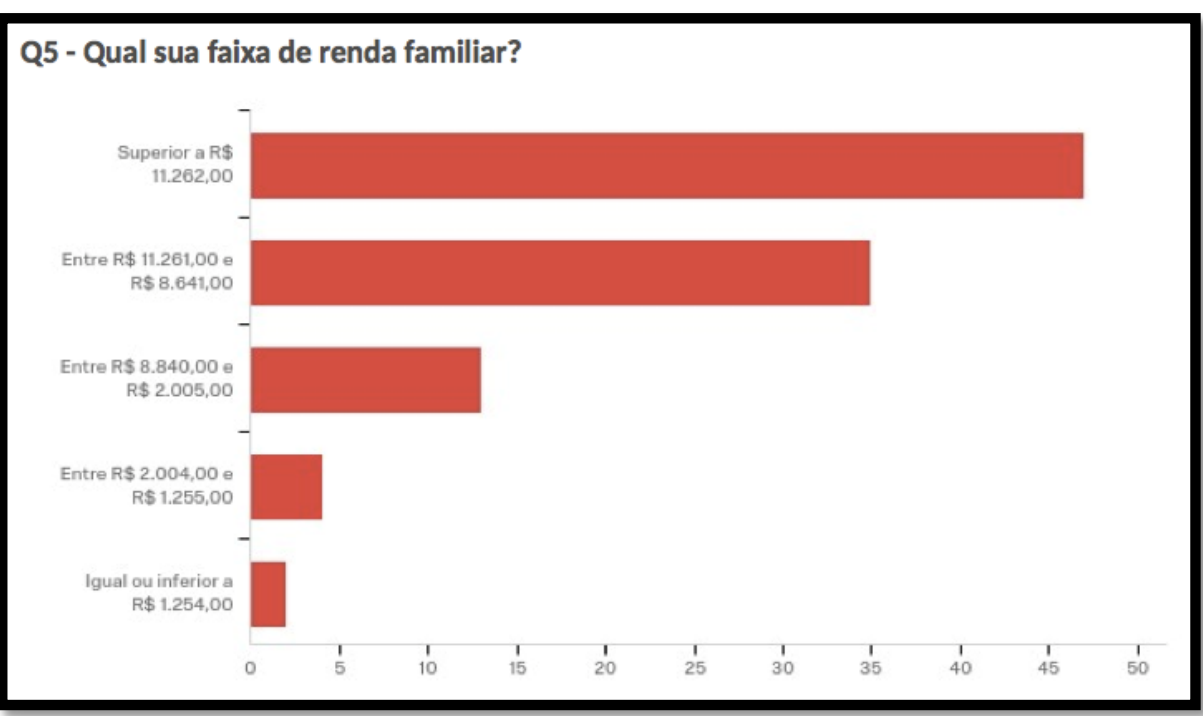

\section{Gráfico 5: Qual sua faixa de renda familiar?}

Q6 - Qual seu grau de escolaridade?

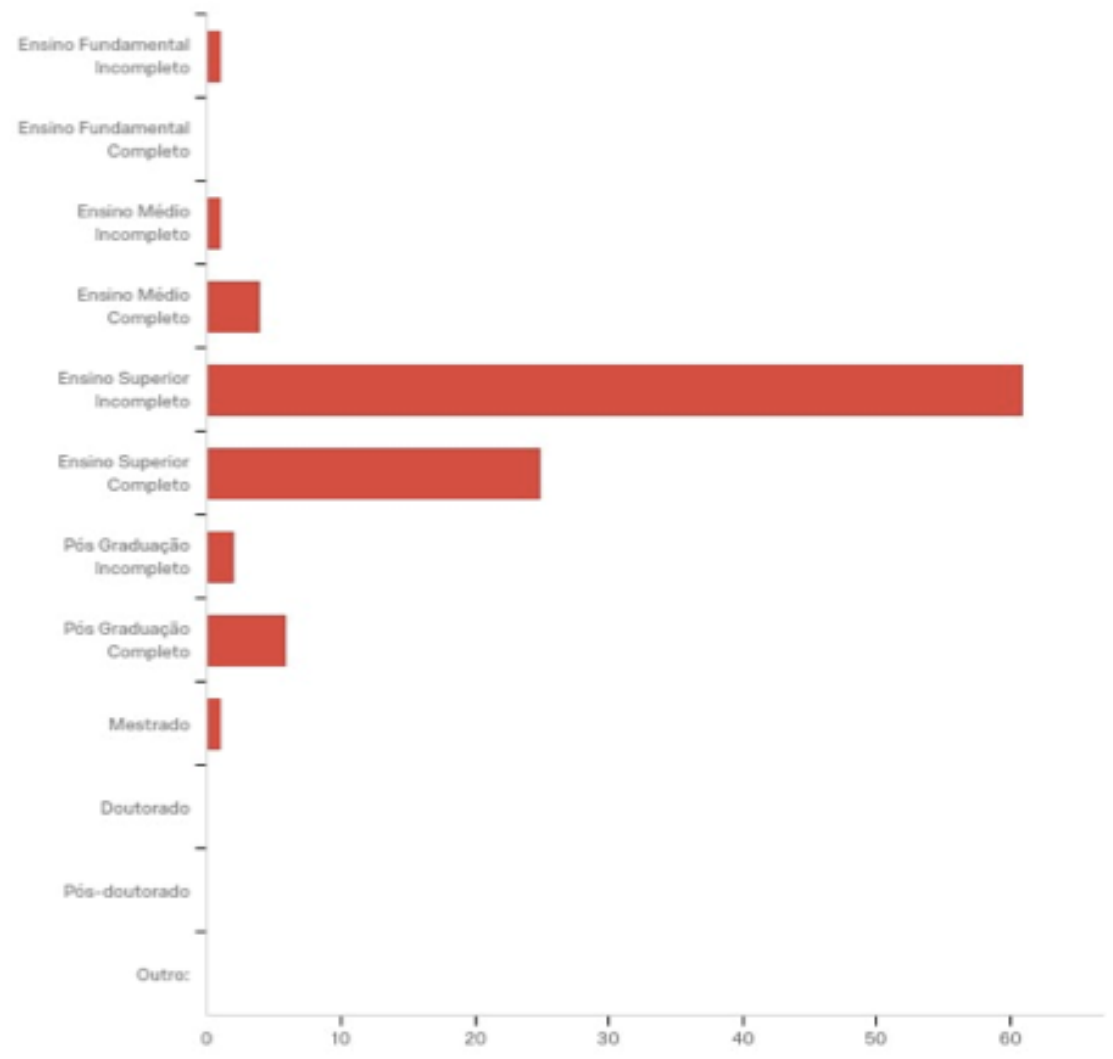


Gráfico 6: Qual seu grau de escolaridade?

Por fim, conforme o gráfico abaixo, $84,16 \%$ dos entrevistados já frequentaram lojas da Farm, onde $83,75 \%$ deles disseram frequentar a loja uma vez a cada dois meses, a cada seis meses ou uma vez ao ano (gráfico 8).

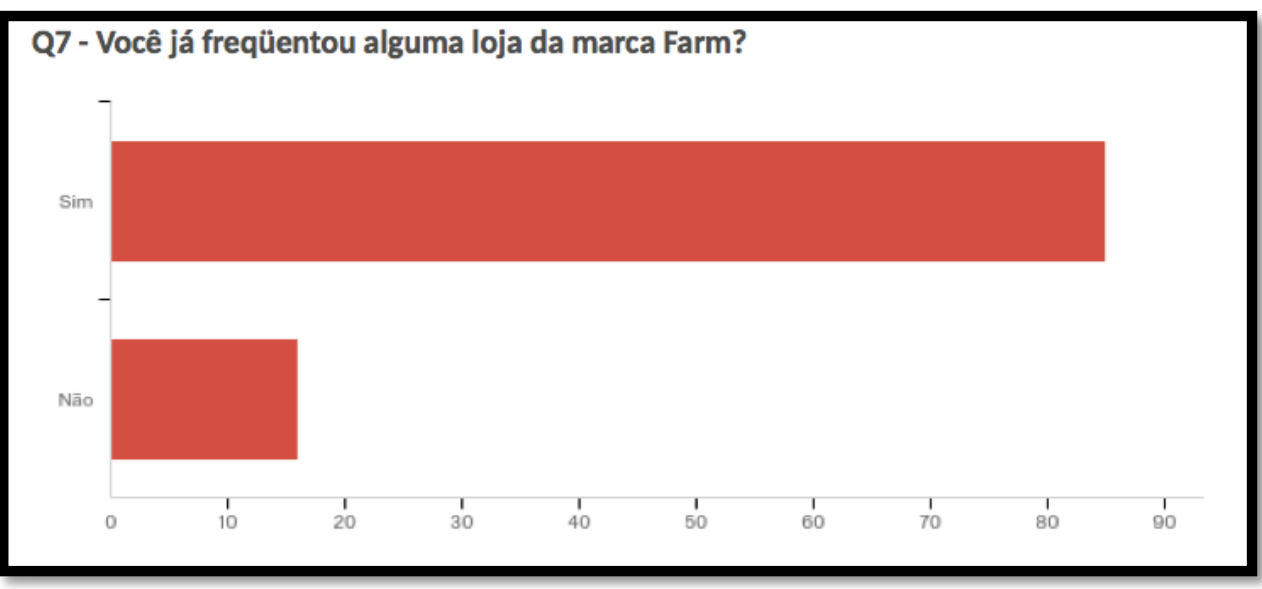

Gráfico 7: Você já frequentou alguma loja da marca Farm?

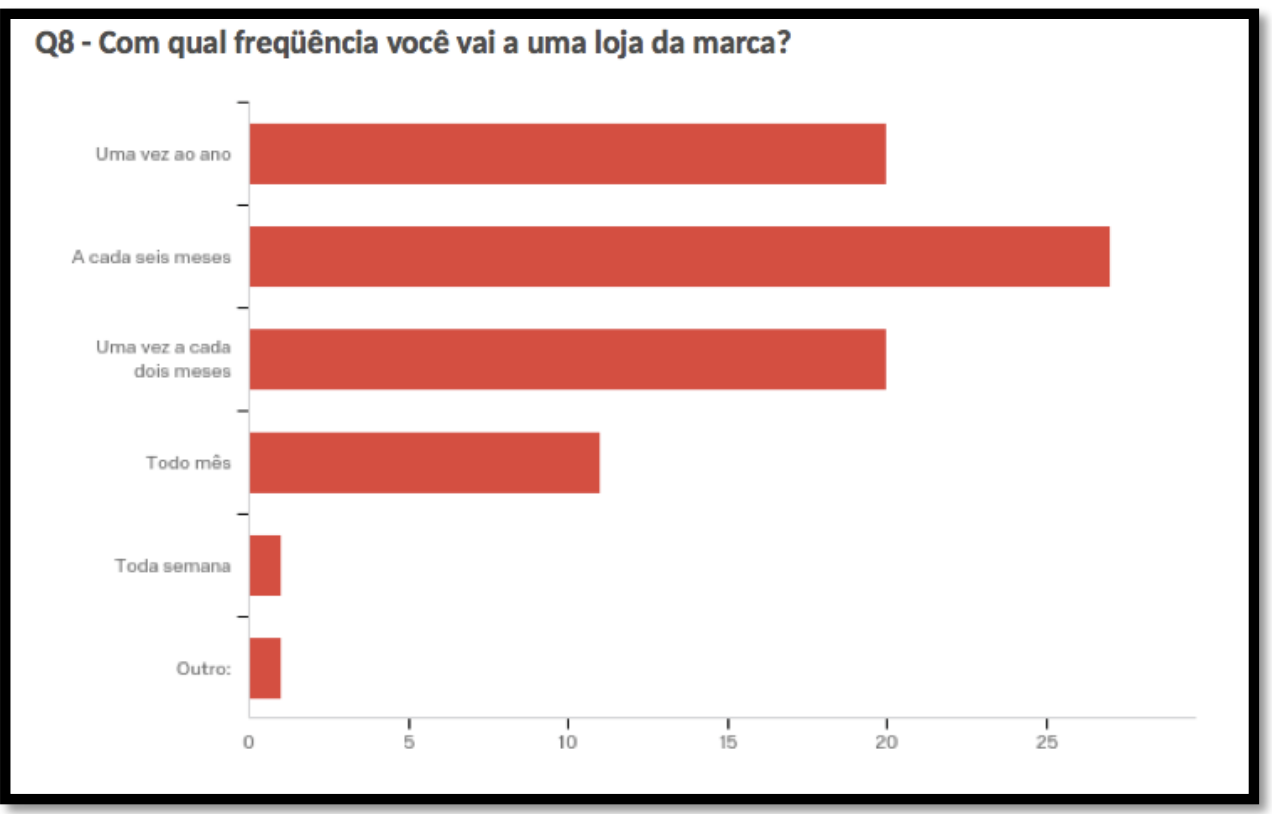

Gráfico 8: com qual frequência você vai a uma loja da marca? 


\subsection{Motivação e desmotivação / Interesses na marca}

O questionário tem a opção para indicar se o entrevistado já entrou ou não em uma loja da Farm. Sendo assim, neste tópico, a análise consiste em verificar o que estimula/motiva e desestimula/desmotiva os entrevistados a entrarem nas lojas da Farm, e o que os interessam na marca.

\subsubsection{Consumidores}

A análise deste tópico é baseada nas respostas dos quase $85 \%$ dos entrevistados que já frequentaram alguma loja da marca. Conforme podemos ver no gráfico 9, a maior parte dos consumidores, são motivados a entrarem nas lojas pela vitrine e pela liquidação, representando $52,59 \%$ da amostra. Um grande número também, $21,48 \%$ dos clientes, são estimulados pela curiosidade em saber se tem peças novas e $14,81 \%$ por estarem à procura de uma peça específica. Apenas 2,96\% disseram se motivar por todas as opções anteriores, e $8,15 \%$ disseram entrar na loja por outros motivos, como para comprar presentes e pelas estampas.

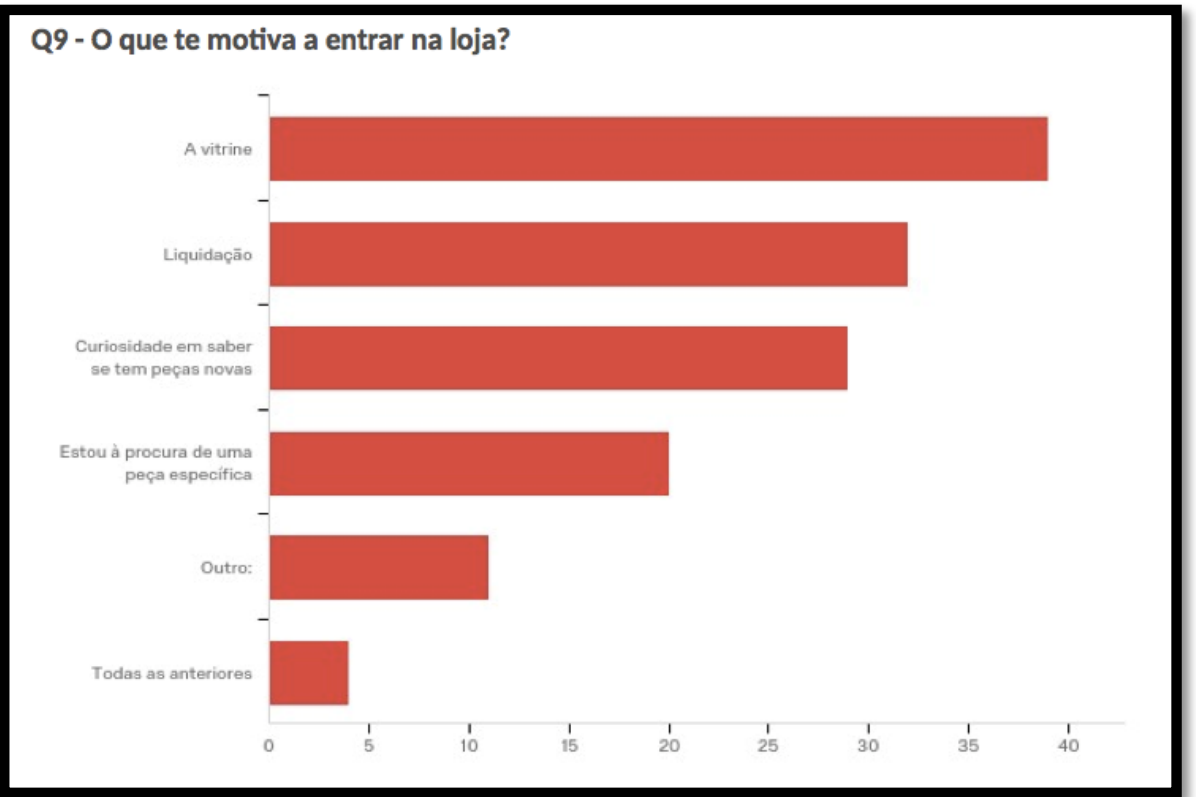

\section{Gráfico 9: 0 que te motiva a entrar na loja?}

Quando os consumidores compram na Farm, eles geralmente estão procurando roupas para o uso cotidiano $(38,60 \%)$ e presentes $(30,70 \%)$ para 
amigas, namorada, irmãs, primas, sobrinhas, filhas/enteadas, netas, cunhada e amigas das filhas. Ainda segundo o gráfico 10, 18,42\% dos consumidores estão à procura de roupas para uma ocasião especial e 9,65\% por causa de uma item específico que só entram lá, como vestidos e saias longas, calças pantalonas, vestidos floridos, quando veem alguém com uma roupa de lá e vão nas lojas atrás deste mesmo item e quando estão à procura de peças para fantasias mais elaboradas ou looks diferentes. Por fim, apenas $2,63 \%$ responderam que quando compram na Farm geralmente estão trocando presentes e estão vendo as novidades.

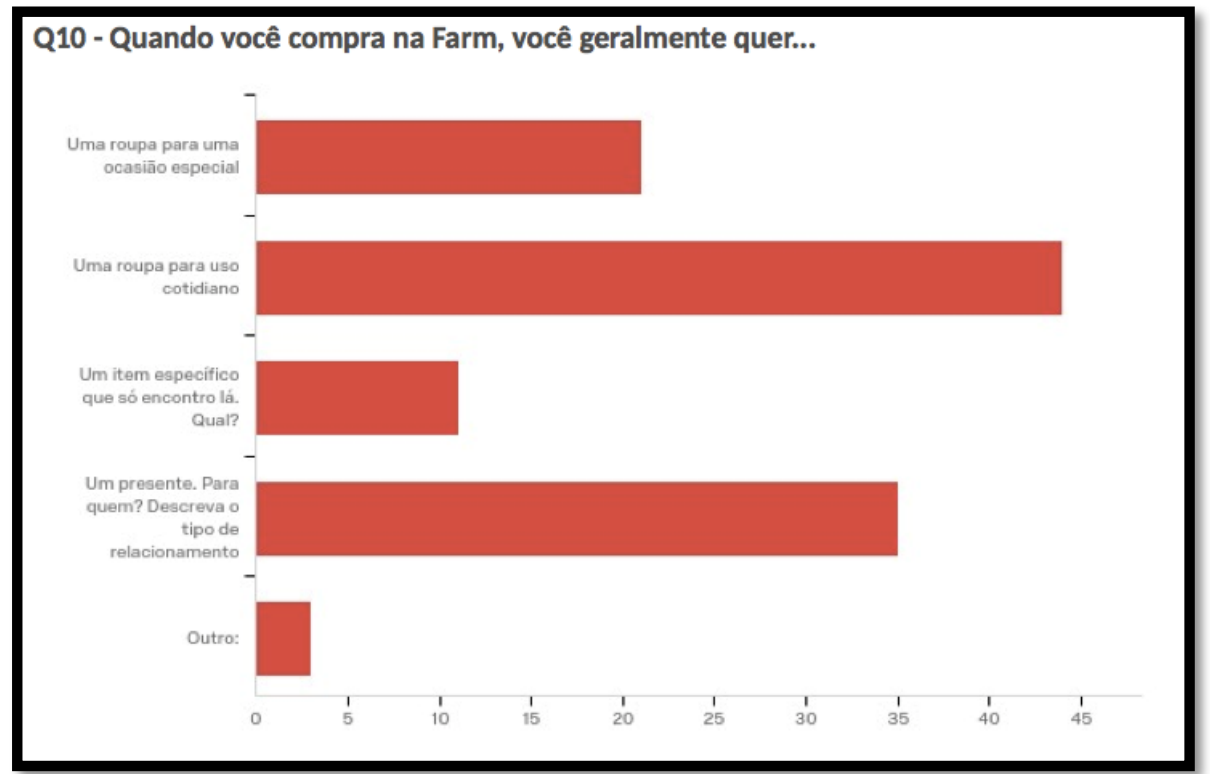

\section{Gráfico 10: Quando você compra na Farm, você geralmente quer...}

$\mathrm{Na}$ questão que aborda os aspectos que desencorajam o consumidor a comprar na Farm, as respostas giram em torno dos seguintes problemas: atendimentos insatisfatórios, com menções sobre vendedoras lentas, antipáticas e não prestativas; a baixa qualidade das roupas, com comentários negativos sobre a modelagem, tecidos e costura; o alto preço, principalmente comparado com a baixa qualidade das peças; o tamanho, onde uma peça tamanho G, parece ser de tamanho $P$, e que raramente encontram peças para quem estão fora dos padrões de magreza; as estampas, que algumas vezes são muito exageradas e chamativas; e o fato de não comercializarem peças masculinas (Apêndice C).

Assim como a Farm, a marca Abercrombie \& Fitch também possui modelagens para mulheres magras, restringindo assim o público. Segundo a 
Revista Vogue (2013), "a marca virou alvo de polêmica na internet pelo posicionamento em relação à grade de numeração excludente - nas lojas, é impossível encontrar as famosas $t$-shirts, por exemplo, em tamanhos XL e XXL assunto que foi retomado por Robin Lewis, autor de The New Rules of Retail: "ele não quer pessoas grandes comprando na sua loja, ele quer pessoas magras e bonitas"'”.

Ainda conforme a Revista Vogue (2013), a reportagem do The New Rules of Retail, ainda compara os tamanhos/modelagem das roupas da Abercrombie com os de outras marcas: enquanto a maior calça da Abercrombie é tamanho 10 (tamanho 38/40 no Brasil), seus concorrentes possuem numerações mais generosas, que vão até o tamanho 18 (número 46 no Brasil).

Já o gráfico 12 é composto pelos elementos que despertam interesse dos clientes da Farm. Como podemos ver, 84,18\% dos respondentes disseram que a decoração, as estampas e os produtos são os elementos que eles mais gostam na Farm. A música e o aroma representam 12,66\% do interesse, e apenas $1,90 \%$ dos consumidores disseram gostar do atendimento. Por fim, uma pequena porcentagem dos clientes disseram não gostar de nenhuma das opções anteriores (1,27\%).

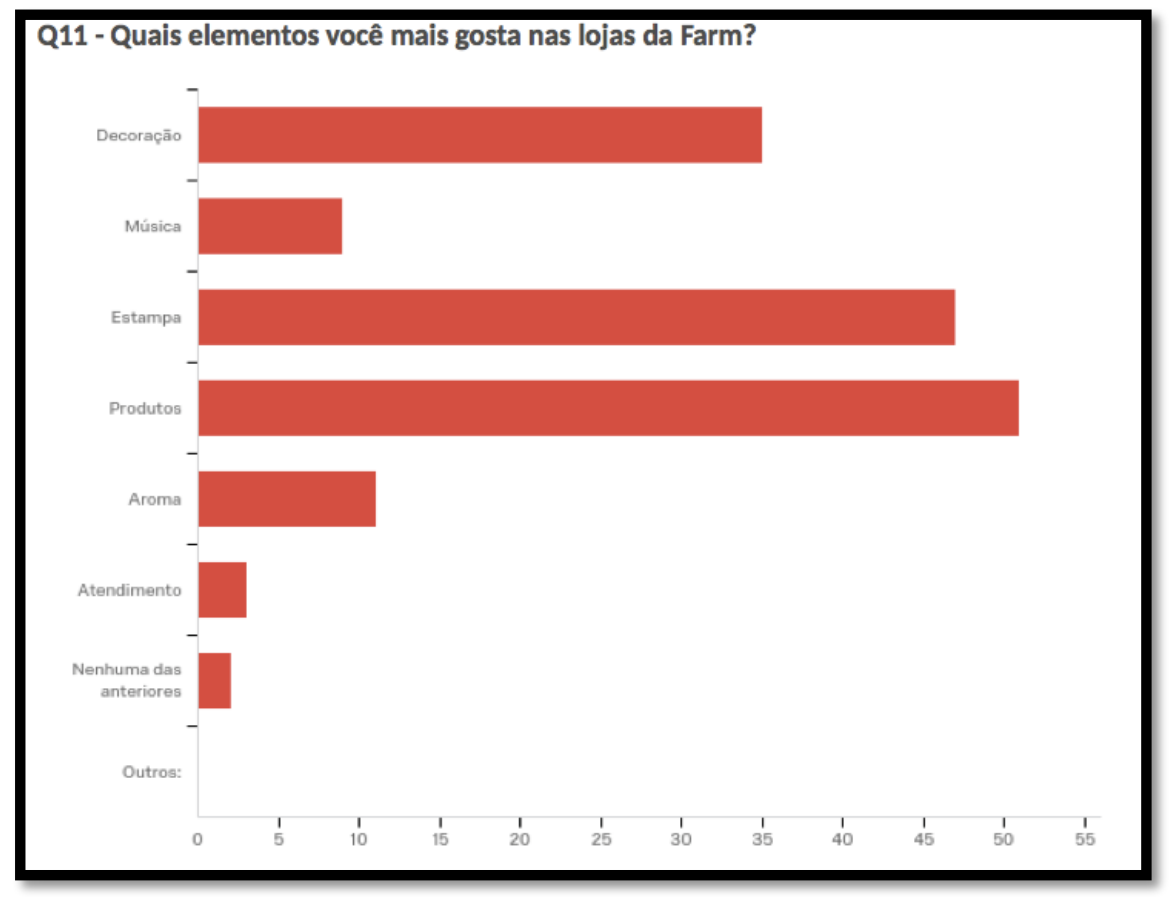

Gráfico 12: Quais elementos você mais gosta nas lojas da Farm? 
$\mathrm{Na}$ questão de quais elementos os clientes não gostam nas lojas da Farm, quase metade dos respondentes escolheram 0 atendimento, representando $44,68 \%$ da amostra, conforme o gráfico 13. A decoração, música, estampa e produtos totalizam $13.83 \%$ das respostas e $21,28 \%$ dos clientes disseram que não tem nenhum elemento citado anteriormente que eles não gostem. $O$ item "outros" foi escolhido por $20,21 \%$ dos consumidores, que disseram não gostar de algumas estampas chamativas, coloridas demais e feias; atendimento ruim; preço alto com baixa qualidade; modelagem, acabamento e qualidade ruins; e alto preço.

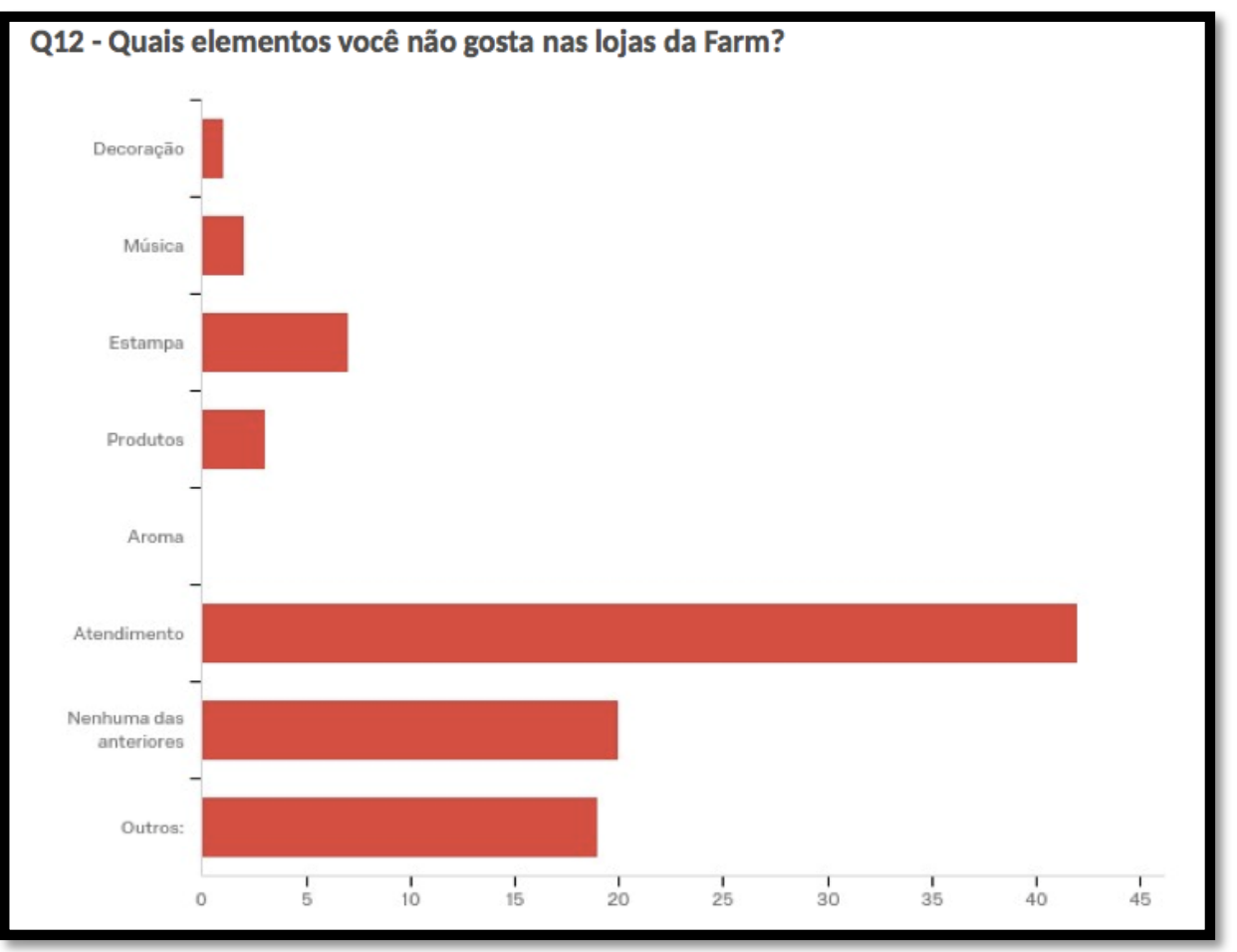

\section{Gráfico 13: Quais elementos você não gosta nas lojas da Farm?}

A maioria dos consumidores, representados por $66,36 \%$ da amostra, responderam que o design das roupas é o diferencial da marca, conforme o gráfico 14. O bom preço, experiências nas lojas e ações promocionais totalizam $23,64 \%$ da escolha dos clientes e $1,82 \%$ dos mesmos disseram que nenhuma das opções anteriores é considerado o diferencial da Farm. Por fim, 8,18\% dos responderam disseram que o diferencial da marca são as estampas e o preço justo, onde é possível comprar peças por menos de $R \$ 200,00$, que dificilmente seria possível em outras lojas. 


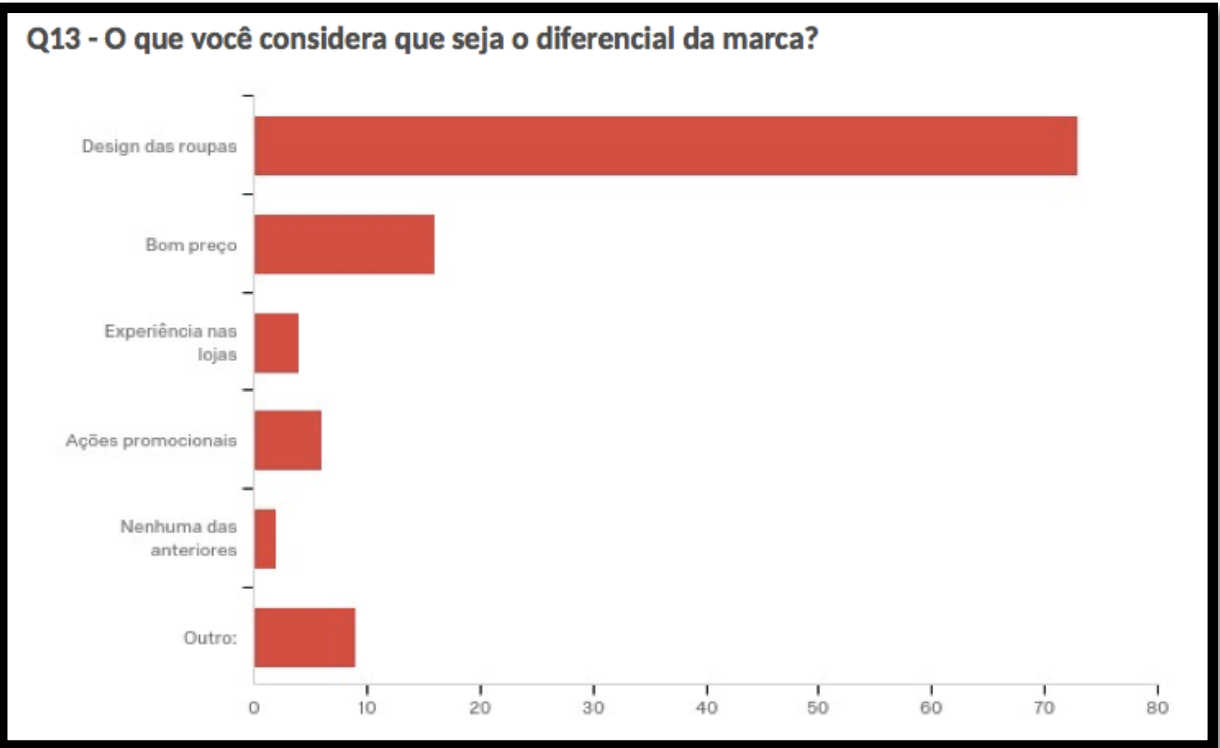

Gráfico 14: O que você considera que seja o diferencial da marca?

\subsubsection{Não Consumidores}

A análise deste tópico é baseada nas respostas dos quase $16 \%$ dos entrevistados, que disseram nunca ter frequentado uma loja da marca. Dentro desta porcentagem de não-consumidores, sua maioria é do sexo masculino $(64,7 \%)$, tem entre 18 e 25 anos $(58,82 \%)$, moram na Zona Sul carioca $(76,47 \%)$, são das classes sociais A e B $(76,47 \%)$, e ainda estão cursando o Ensino Superior (70,58\%).

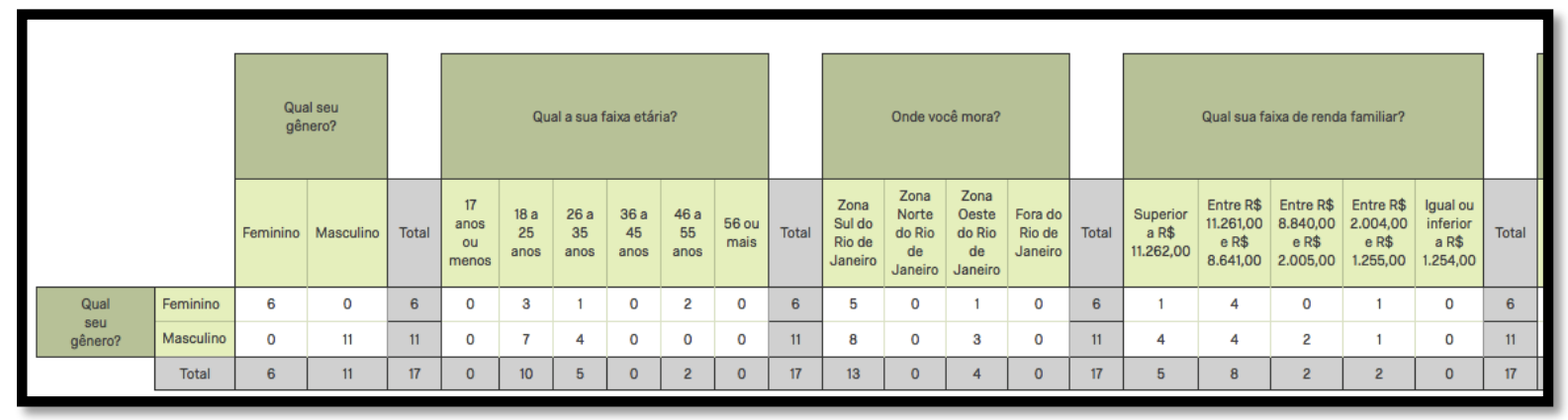




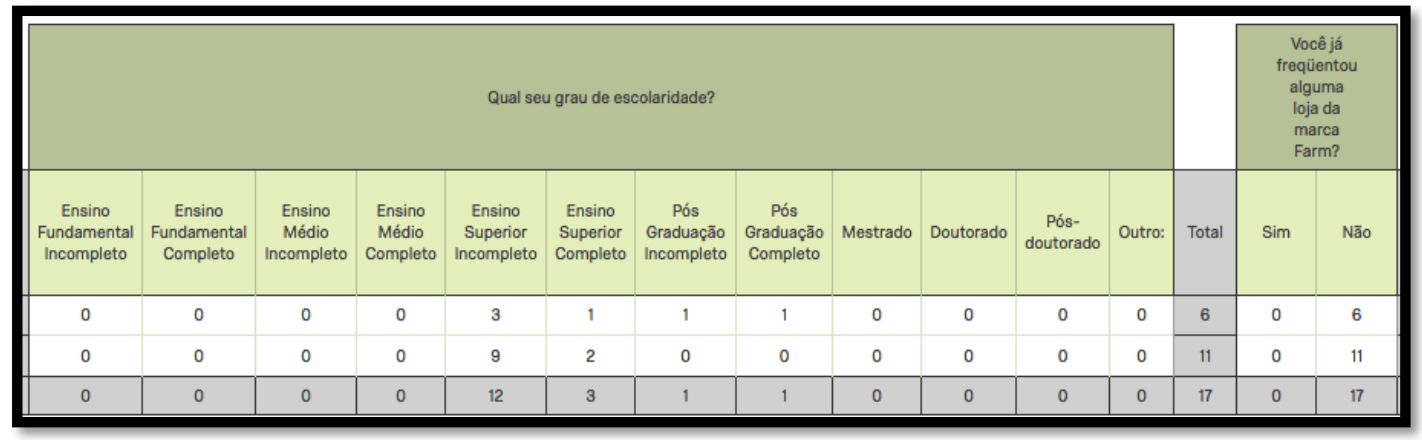

Tabela 1: Perfil dos não-consumidores da Farm

Quando indagado aos não consumidores da marca quais são os aspectos que os desencorajam a entrar na loja da Farm, a maioria respondeu os "produtos", representando 40,91\% da amostra. Ainda segundo o gráfico 15, em segundo lugar o "design das roupas", com 22,73\%, em terceiro lugar "a vitrine", representado com 18,18\%, e em último lugar o "atendimento", com 4,55\%. Também com este pequeno percentual de $4,55 \%$ foi escolhido a opção "todas as anteriores". Outros aspectos, como ser do sexo masculino e a loja vender apenas artigos femininos foram escolhidos por $9,09 \%$ dos respondentes.

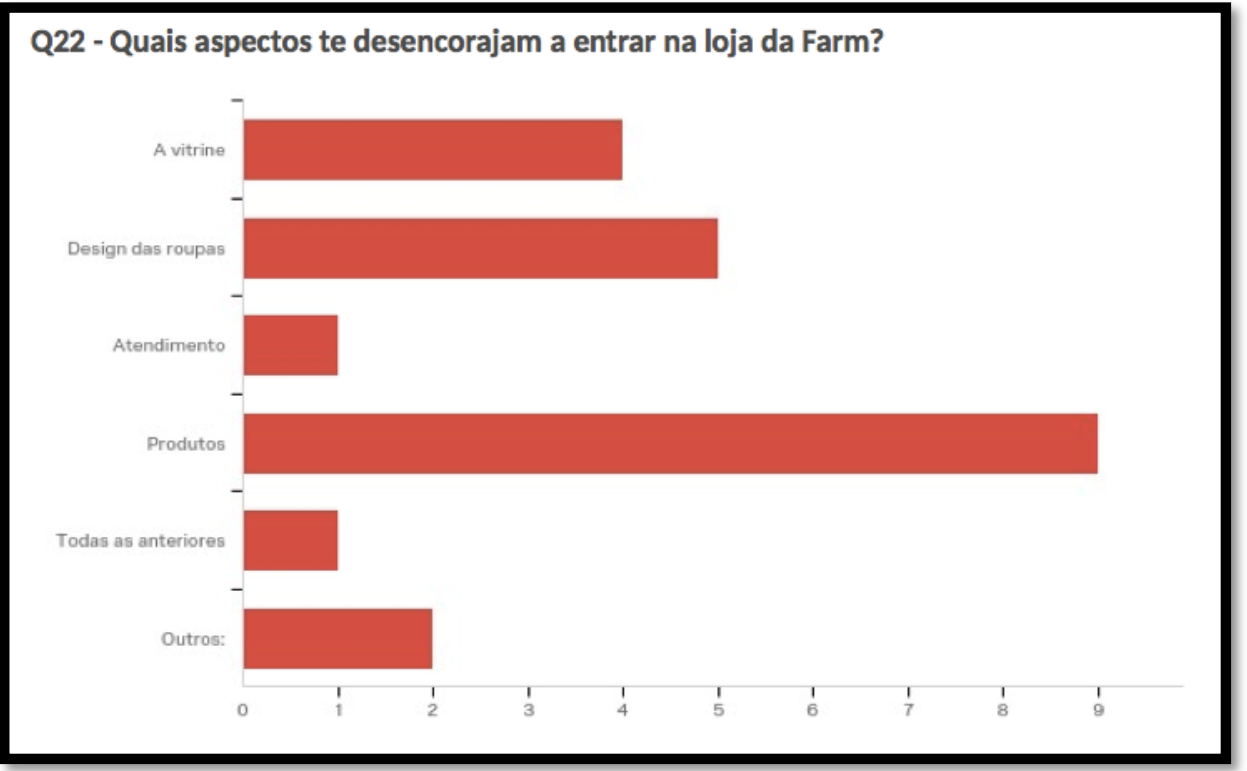

Gráfico 15: Quais aspectos te desencorajam a entrar na loja da Farm?

$\mathrm{Na}$ questão de quais elementos despertam mais interesse na loja, $22,22 \%$ dos não clientes elegeram a decoração e $11,11 \%$ deles escolherem os produtos, conforme o gráfico 16 . O atendimento e a música ficaram empatados, 
ambos com 5,56\% das escolhas. Já a estampa e o aroma não foram escolhidos por ninguém. A maioria dos não consumidores escolherem a opção "nenhuma das anteriores", onde não gostam de nenhum elemento na loja, representado por $55,56 \%$ da amostra.

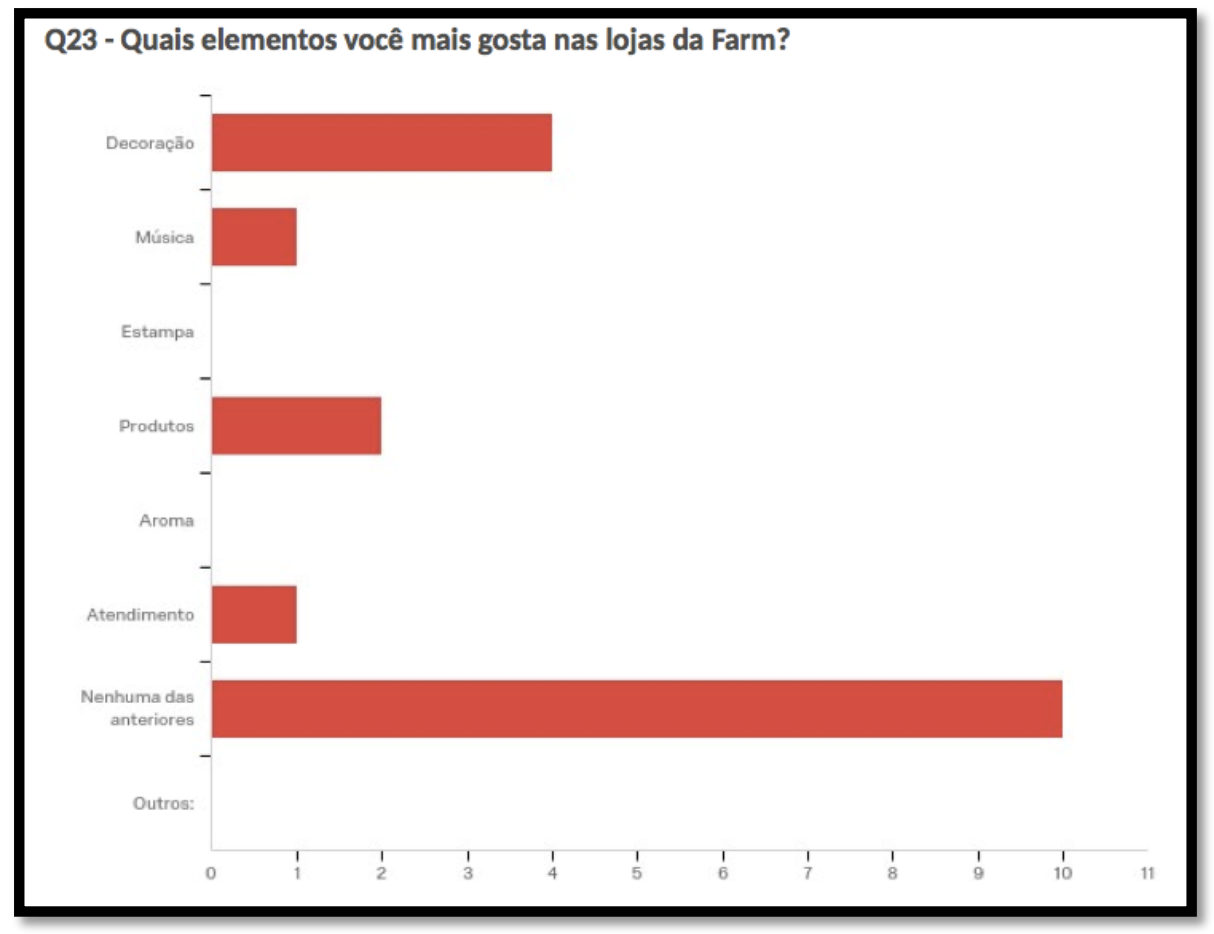

\section{Gráfico 16: Quais elementos você mais gosta nas lojas da Farm?}

Por fim, na questão onde foi indagado quais elementos os despertam menos interesse na Farm, tanto a estampa como os produtos foram escolhidos com $22,22 \%$ cada um, de acordo com o gráfico 17 . Com $5,56 \%$ cada um, o atendimento e a decoração foram as escolhas dos entrevistados. Já o aroma e a música não foram escolhidos por ninguém. A maioria dos entrevistados responderam que não gostam de nenhuma das opções anteriormente sugeridas, com $44,44 \%$ da amostra. 


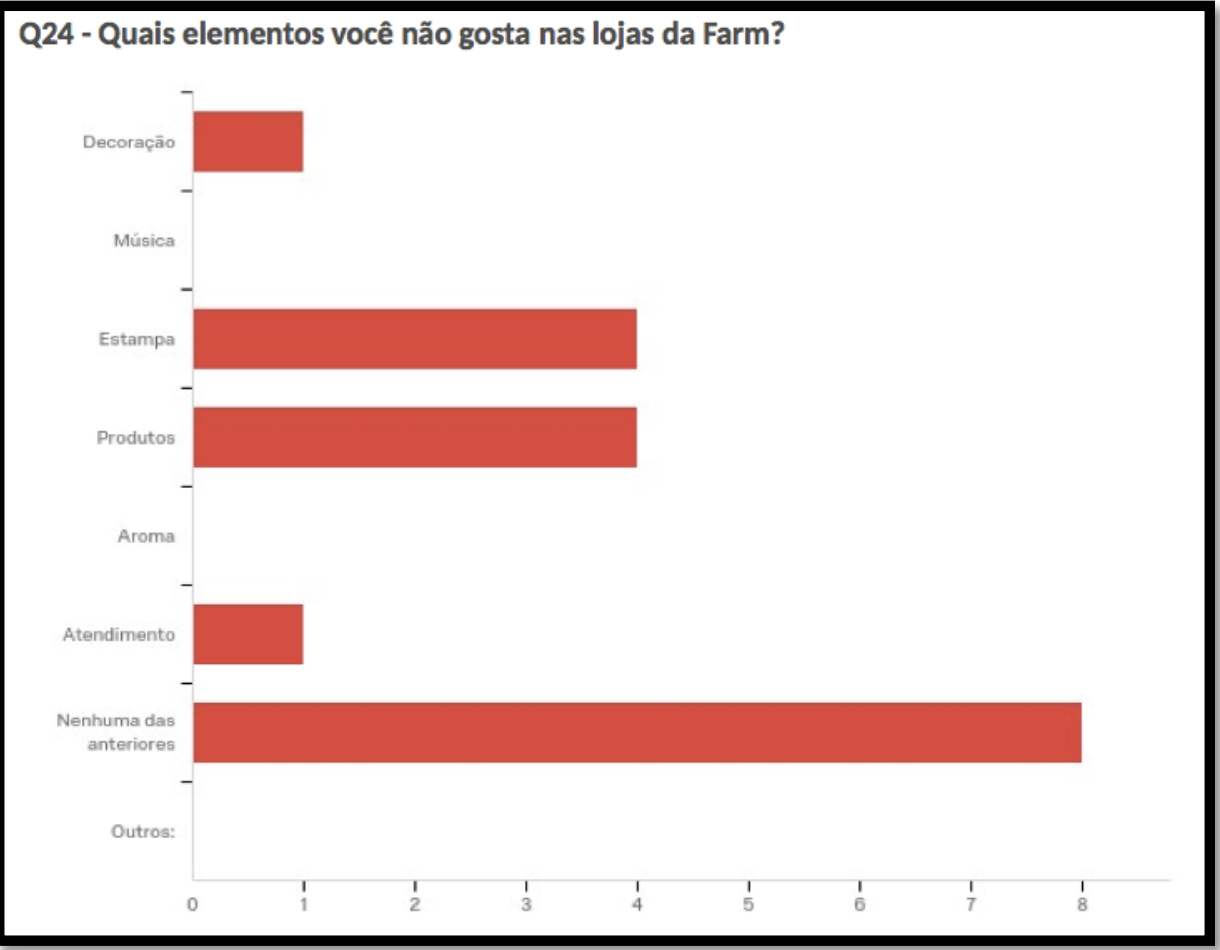

\section{Gráfico 17: Quais elementos você não gosta nas lojas da Farm?}

\subsection{Associações à marca}

Neste tópico será analisado as associações feitas pelos consumidores e não consumidores à marca.

\subsubsection{Consumidores}

A questão que aborda quais cores os clientes associam à Farm, conforme o gráfico 18, podemos ver que a cor amarela foi escolhida por $17,99 \%$ dos consumidores, $12,95 \%$ escolheram a cor verde, a cor laranja foi escolhida por $12,23 \%$, a cor azul por $10,07 \%$ e a cor vermelha por apenas, $4,32 \%$ amostra. A opção de todas as cores anteriores foi escolhida por 35,25\% dos respondentes, transparecendo que a maioria dos consumidores associam à Farm a um conjunto de cores. Apenas $2,88 \%$ da amostra disseram que associam à marca as cores branco e rosa e que é uma marca muito colorida. 


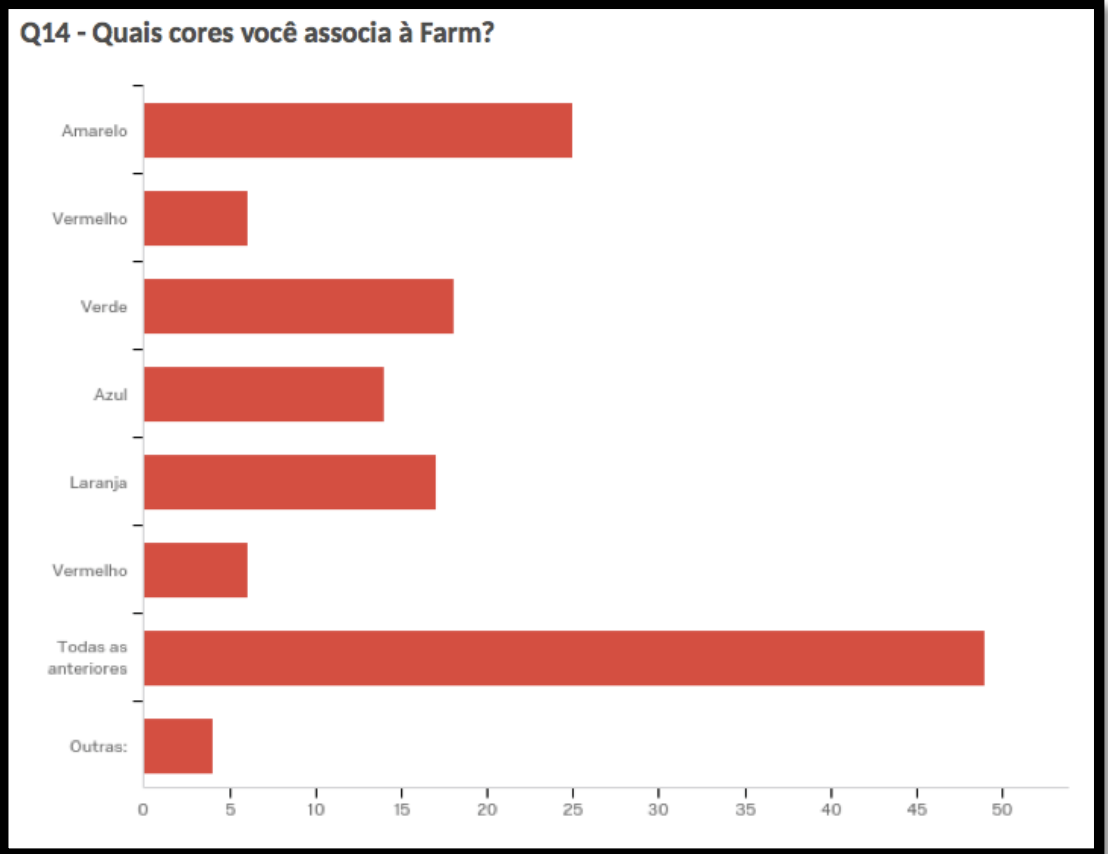

\section{Gráfico 18: Quais cores você associa à Farm?}

No gráfico 19, podemos ver que mais de $85 \%$ dos consumidores responderam que associam a cidade do Rio de Janeiro à marca, e 13,83\% a cidade de Salvador. Notavelmente, ninguém associou às cidades de São Paulo e de Nova York, bem mais urbanas e corporativas.

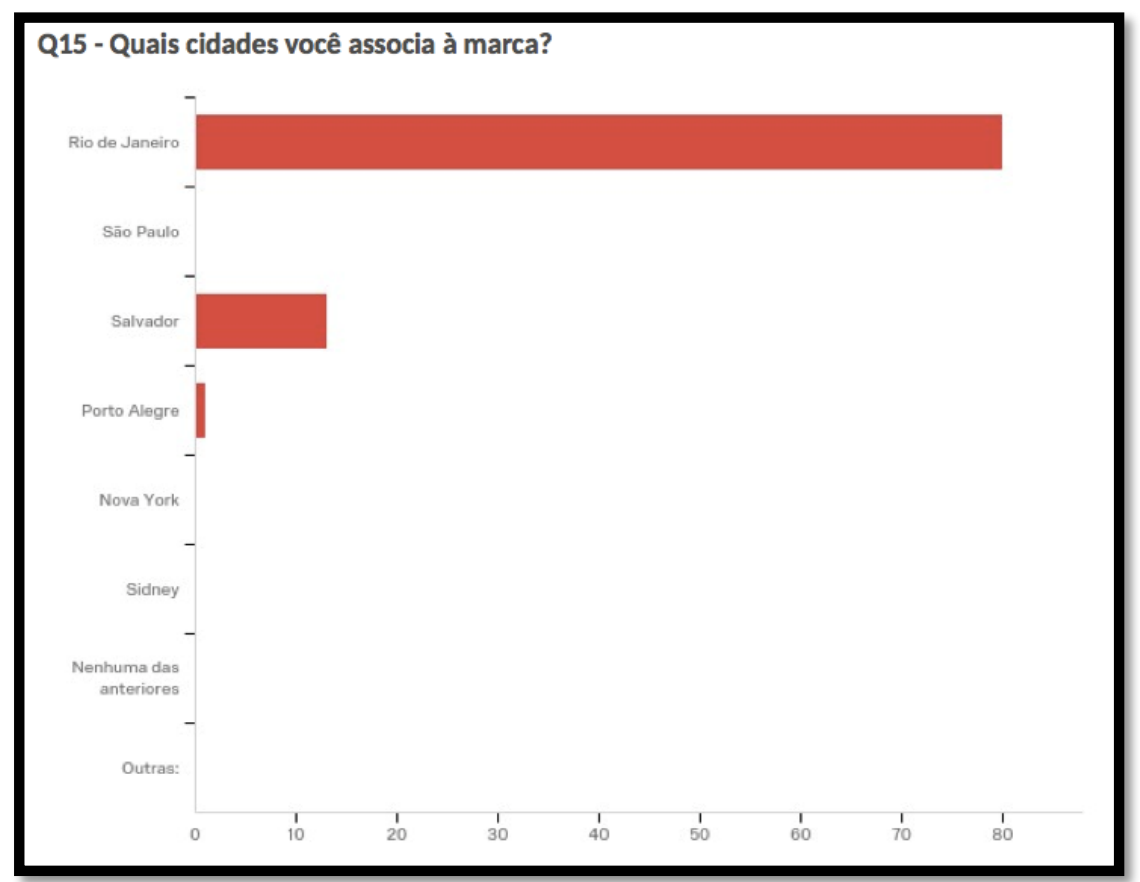

Gráfico 19: Quais cidades você associa à marca? 
No item que aborda quais situações são associadas à Farm, a maioria dos clientes responderam passear ao ar livre $(28,25 \%)$, sair para almoçar $(23,77 \%)$ e fazer um picnic $(21,08 \%)$, que são situações bem informais e despojadas. Ainda no gráfico 20, é possível ver que ir à faculdade foi escolhido por 9,42\% e passear no shopping por $13 \%$. A opção trabalhar não foi escolhida por ninguém e apenas $2,24 \%$ dos respondentes associam todas as situações anteriores à marca. Uma pequena amostra, composta por 2,24\%, escolherem outras situações, como ir à festas, praia e Carnaval.

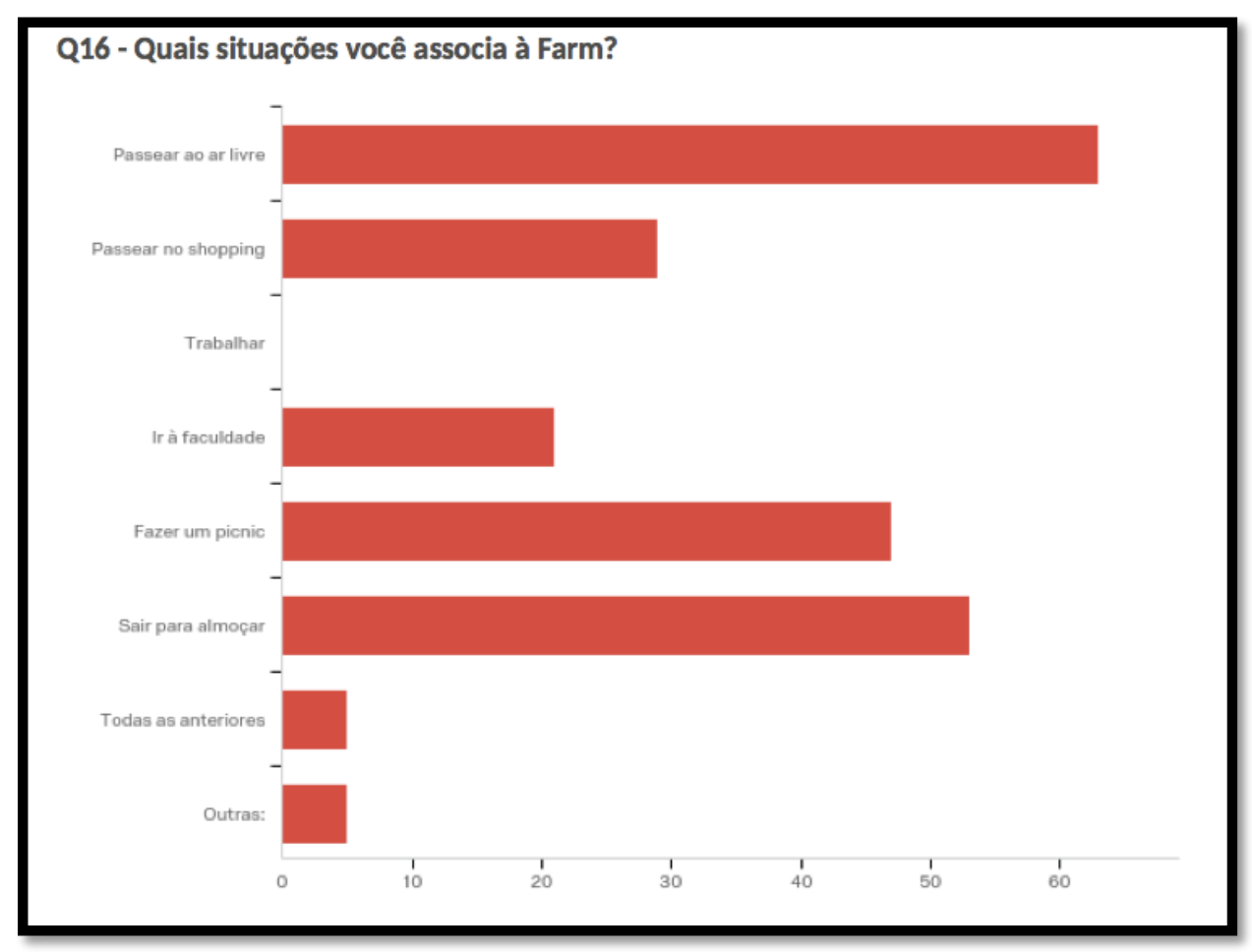

\section{Gráfico 20: Quais situações você associa à Farm?}

A maior parte dos entrevistados responderam que a emoção "alegria" mais se associa à Farm, representando 77,45\% da amostra, conforme o gráfico 21 . Ninguém associou "tristeza" e "aversão" à marca, e tanto "confiança" quanto "surpresa" foram escolhidas por 9,80\% dos respondentes cada uma. Apenas $0,98 \%$ da amostra não associa nenhuma das opções anteriores à marca, e $1,96 \%$ disseram que associam à marca as opções "despojada" e "leveza, simplicidade". 


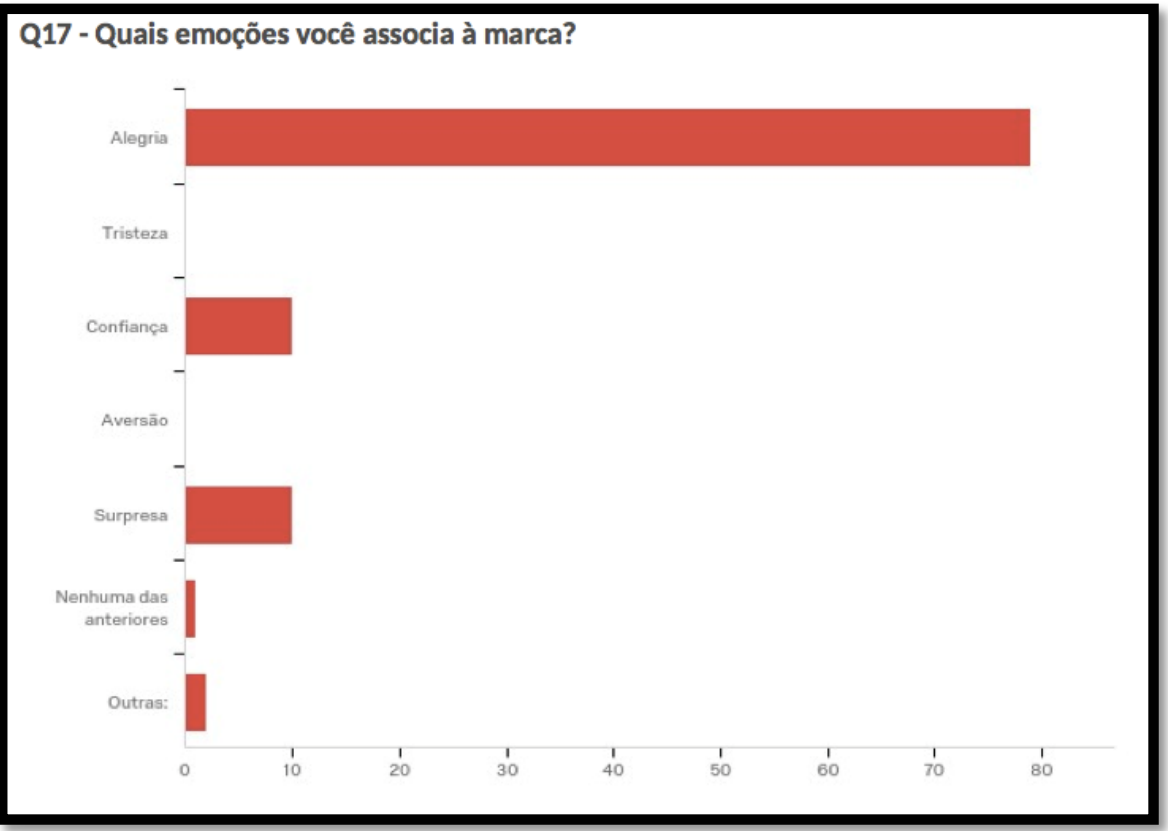

\section{Gráfico 21: Quais emoções você associa à marca?}

Em relação ao estilo musical que os clientes associam à marca, a maior parte escolheu o "MPB", representando 61,32\% da amostra, em segunda posição o "hip hop", com $24,53 \%$ das respostas, e em terceira posição o "rock" com apenas $4,72 \%$. Ainda de acordo com o gráfico 22, ninguém associou o funk e o sertanejo à Farm. Apenas 5,66\% dos clientes não associaram nenhuma das opções anteriores e 3,77\% escolheram o "pop" e o "indie" como estilo musical.

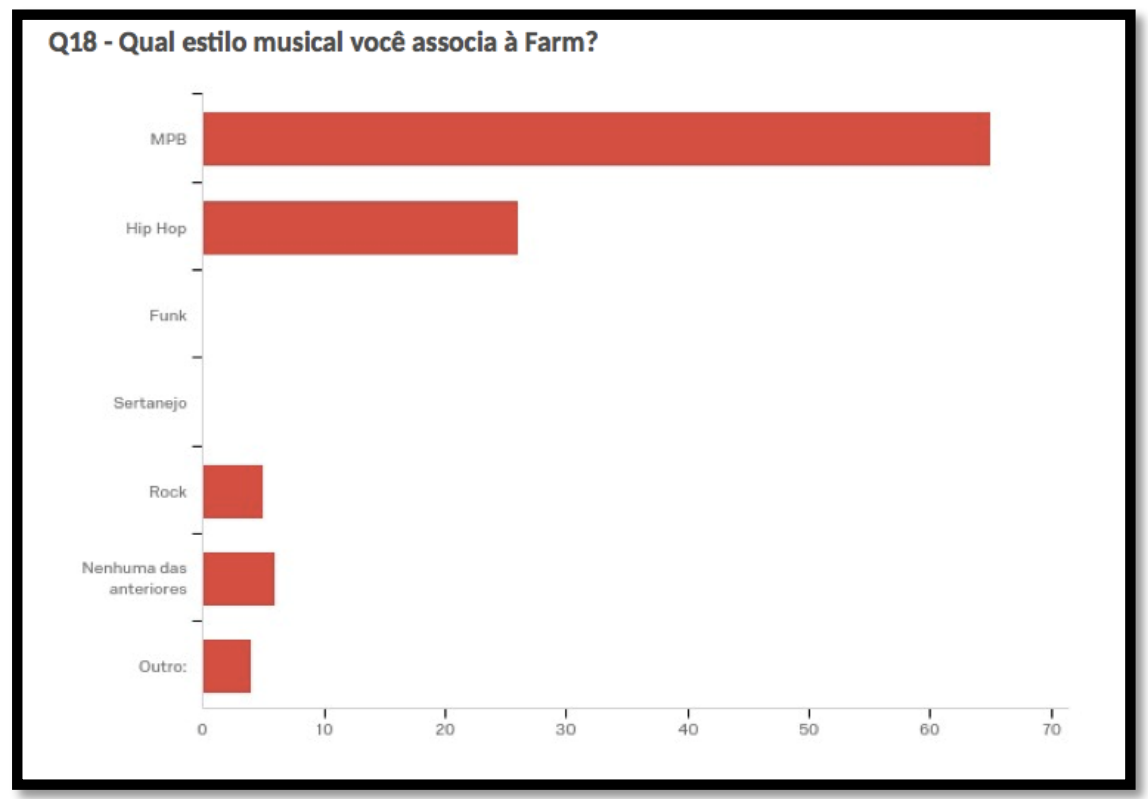

Gráfico 22: Qual estilo musical você associa à Farm? 
Conforme o gráfico 23, quase $100 \%$ dos entrevistados acreditam que "meninas universitárias moradoras da zona sul carioca" é o perfil que mais se aproxima de um consumidor típico da Farm. Apenas 2,5\% responderam "meninas que moram fora do Rio de Janeiro", e ninguém escolheu a opção "mulheres cariocas acima de 30 anos". Uma pequena amostra associou todas as opções anteriores como consumidores típicos da marca $(2,5 \%)$.

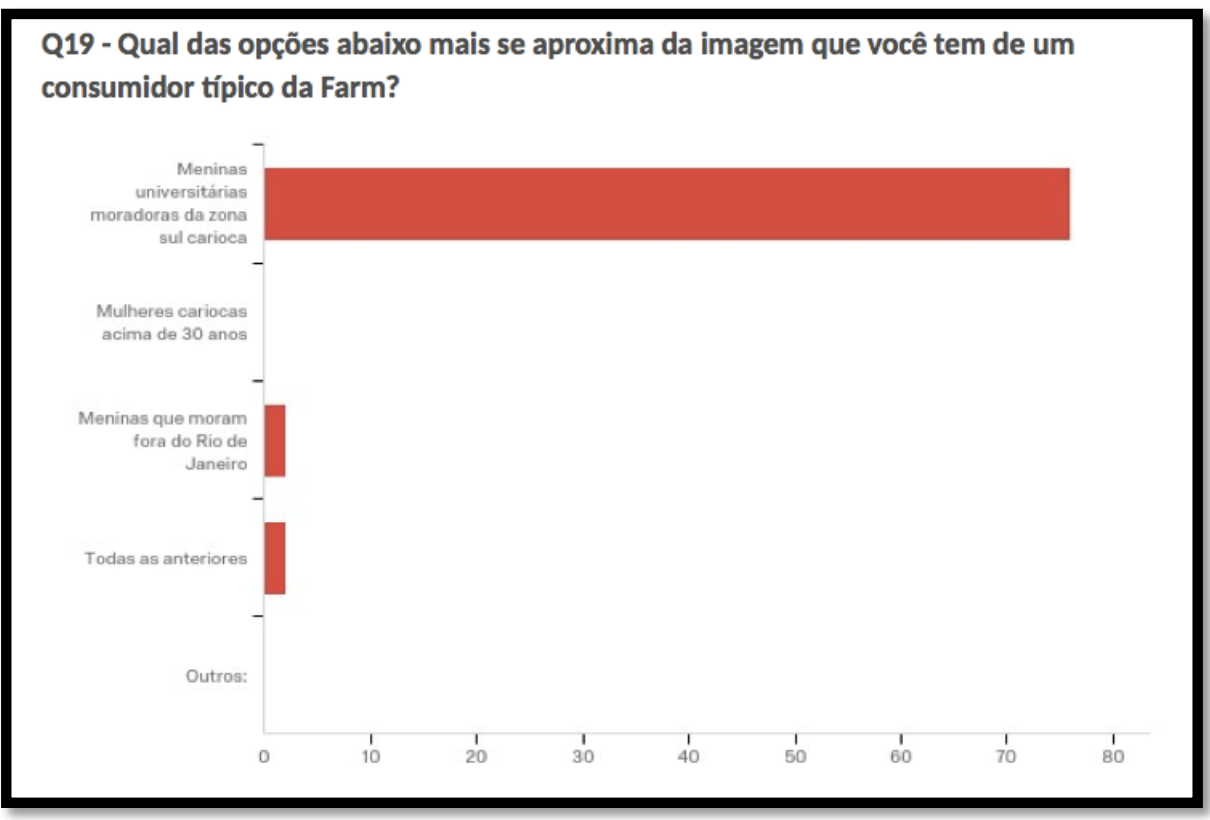

Gráfico 23: Qual das opções abaixo mais se aproxima da imagem que você tem de um consumidor típico da Farm?

Por fim, 58,75\% dos respondentes disseram que acham que a Farm dialoga com eles, conforme o gráfico abaixo. Os consumidores que consideram que a marca não dialoga com eles são representados por $41,25 \%$ da amostra. Dentro deste percentual, a maioria dos entrevistados é do sexo feminino $(87,87 \%)$, tem entre 18 e 25 anos (54,54\%), mora na Zona Sul do Rio de Janeiro $(72,72 \%)$, é das classes sociais A e B $(81,81 \%)$ e ainda está cursando ou já completou o Ensino Superior (87,87\%). Podemos dizer assim, que estes consumidores frequentam à loja para comprar ou trocar presentes ou apenas para ver as novidades de curiosidade. 

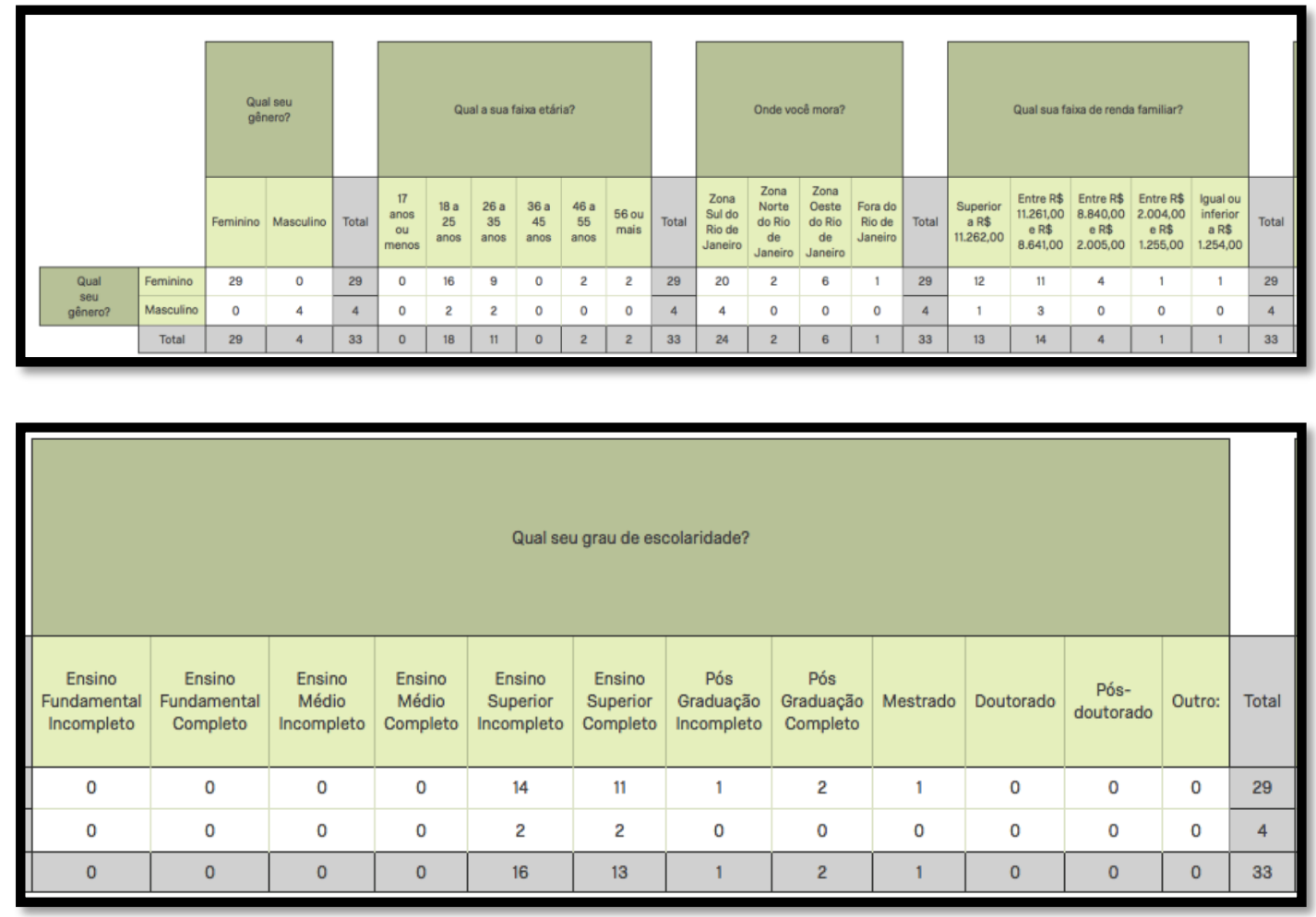

Tabela 2: Perfil dos consumidores da Farm que dizem que a marca não dialoga com eles

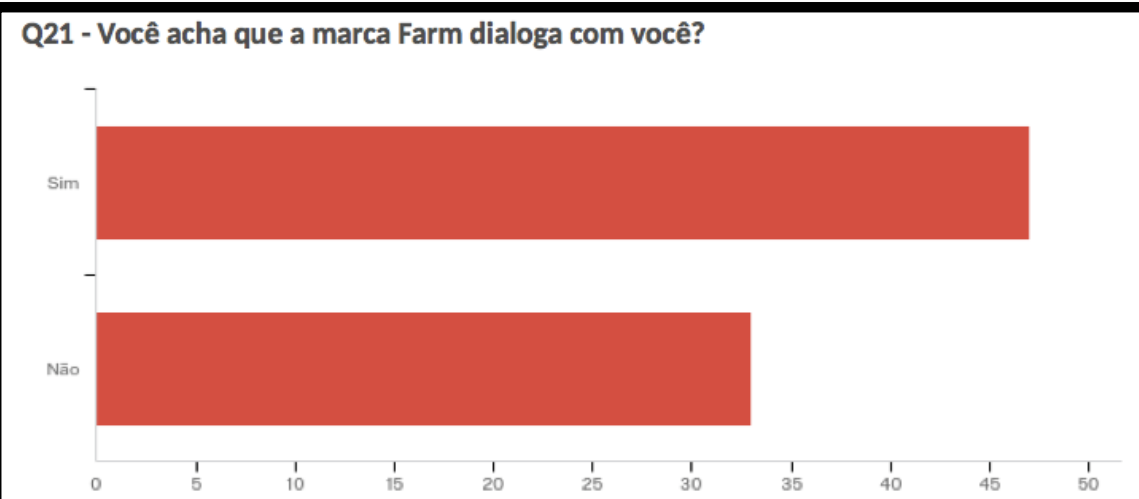

Gráfico 24: Você acha que a marca Farm dialoga com você?

\subsubsection{Não Consumidores}

Os entrevistados que não consomem na Farm associam a cor amarela à marca, representando $15 \%$ da amostra, como o gráfico 25 . A cor verde foi escolhida por $10 \%$ dos entrevistados e a laranja por $5 \%$. Já as cores vermelho e 
azul não foram escolhidas por ninguém. A maioria dos entrevistados, representando $60 \%$, associam todas as cores anteriores à marca. Apenas $10 \%$ dos respondentes escolheram a cor branca.

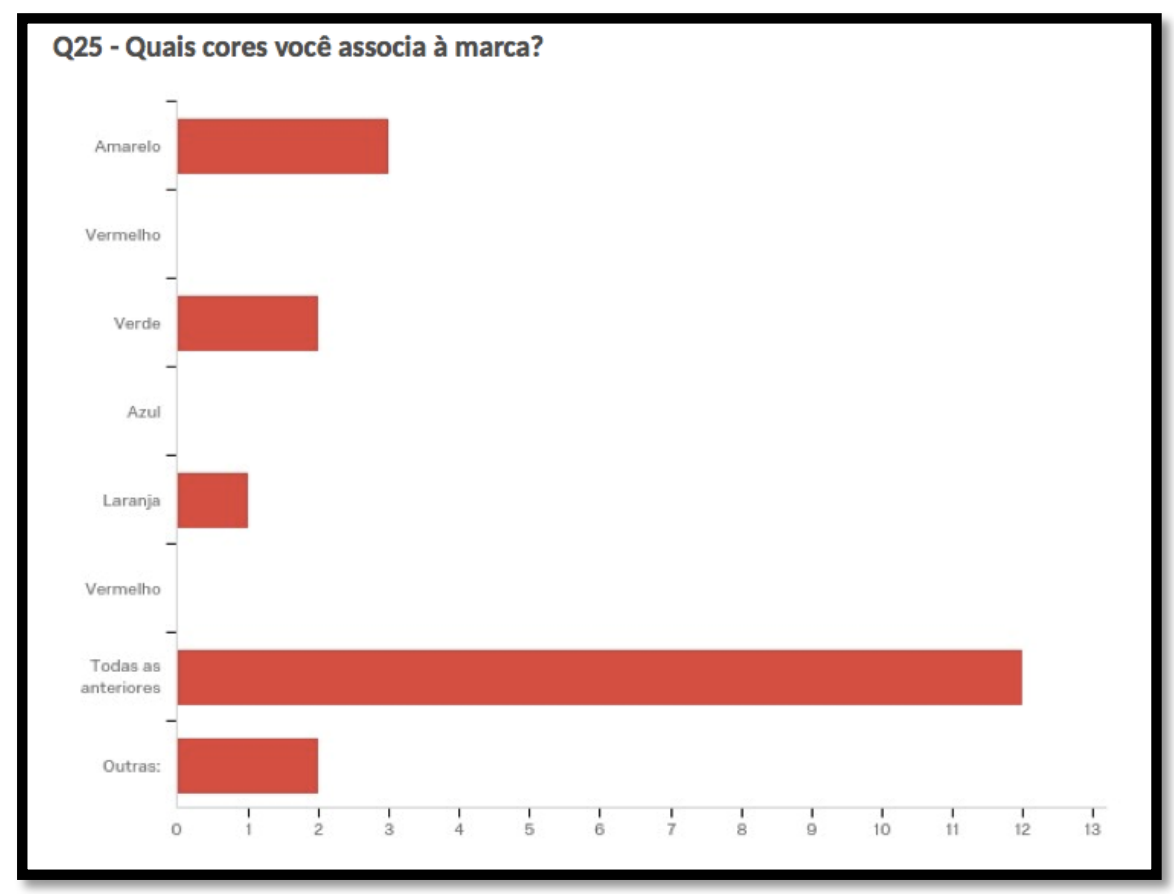

Gráfico 25: Quais cores você associa à marca?

Conforme o gráfico abaixo, a maior parte dos indagados associam o Rio de Janeiro à marca, representando 78,95\% da amostra. Em segundo lugar, com 10,53\%, escolheram São Paulo e com 5,26\%, Salvador. As opções de cidades como Porto Alegre, Nova York e Sidney não foram associadas. Também com $5,26 \%$, os entrevistados disseram não associar nenhuma das cidades anteriormente citadas à Farm. 


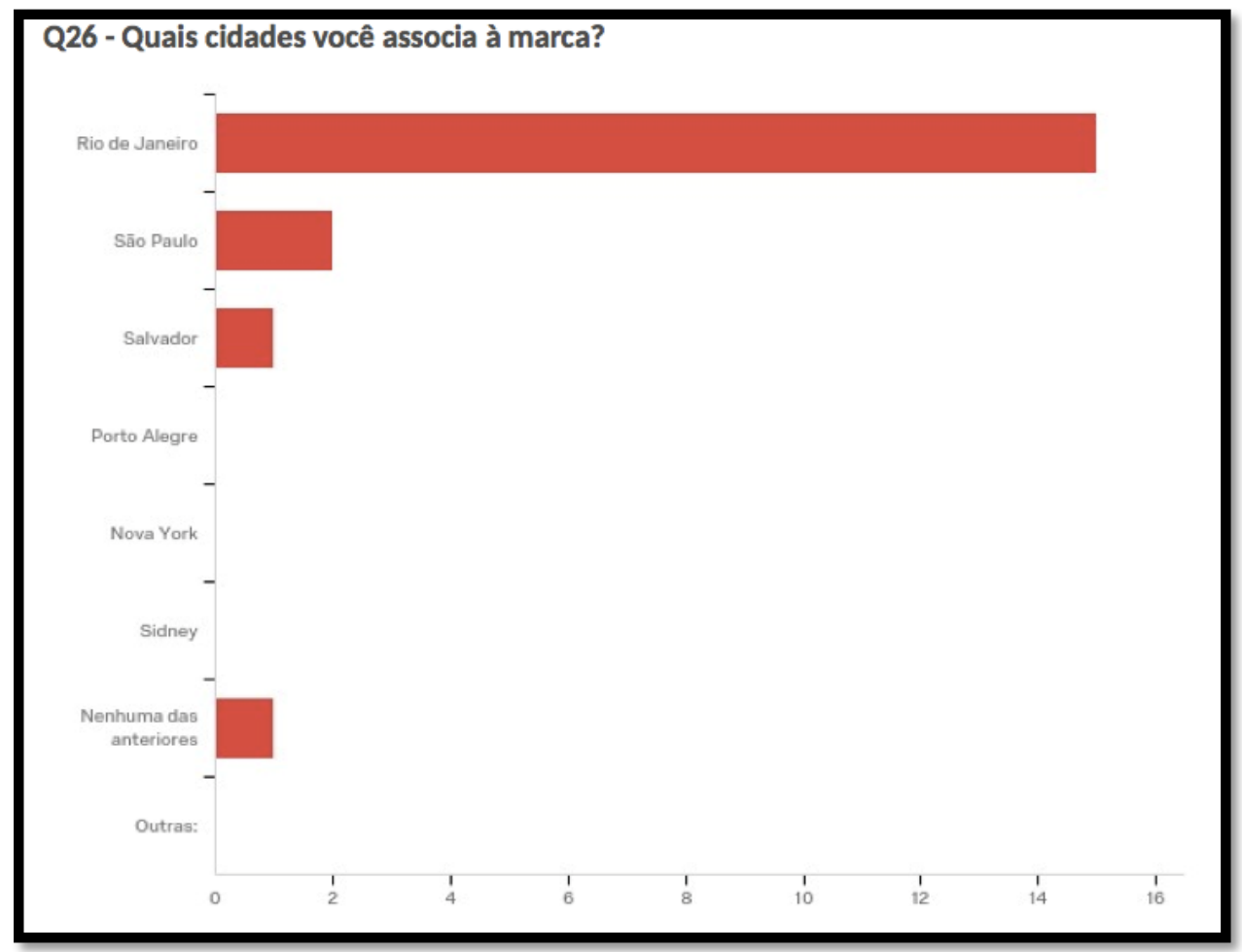

\section{Gráfico 26: Quais cidades você associa à marca?}

A maioria dos não clientes da marca $(41,94 \%)$ associaram a situação "passear ao ar livre" à Farm. Ainda conforme o gráfico 27, "fazer um picnic" ficou em segundo lugar (19,35\%), em terceiro ficou "sair para almoçar" (16,13\%), em quarto "passear no shopping" (12,90\%), em quinto "ir à faculdade" $(3,23 \%)$ e por último, "trabalhar" não foi escolhido por ninguém. Por fim, 6,45\% dos respondentes disseram que associam todas as opções anteriores à marca. 


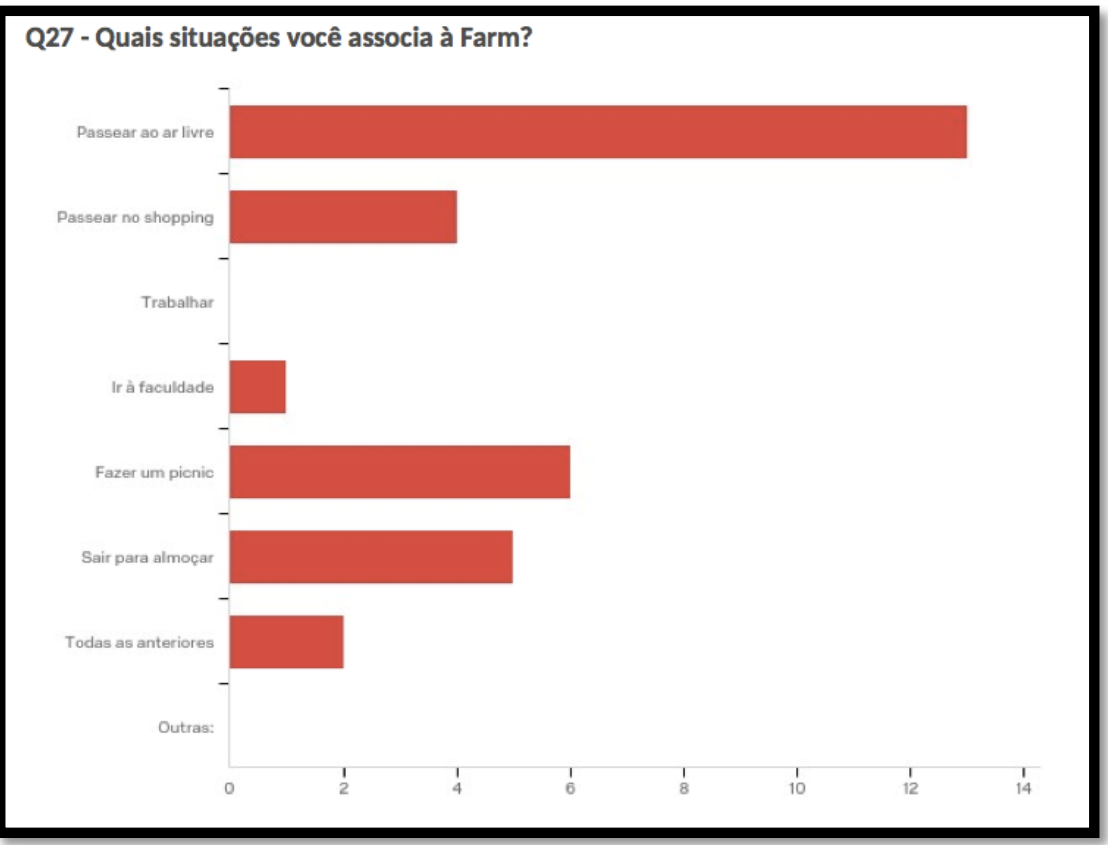

\section{Gráfico 27: Quais situações você associa à Farm?}

Quando indagados quais emoções associam à marca, os respondentes, representando $82,35 \%$ da amostra, escolheram "alegria", conforme o gráfico abaixo. Confiança e aversão foram escolhidos, cada um, por 5,88\% dos entrevistados. Já "tristeza" e "surpresa" não foram associados por nenhum dos não clientes. Também com 5,88\%, a opção "nenhuma das anteriores" foi escolhida pelos respondentes.

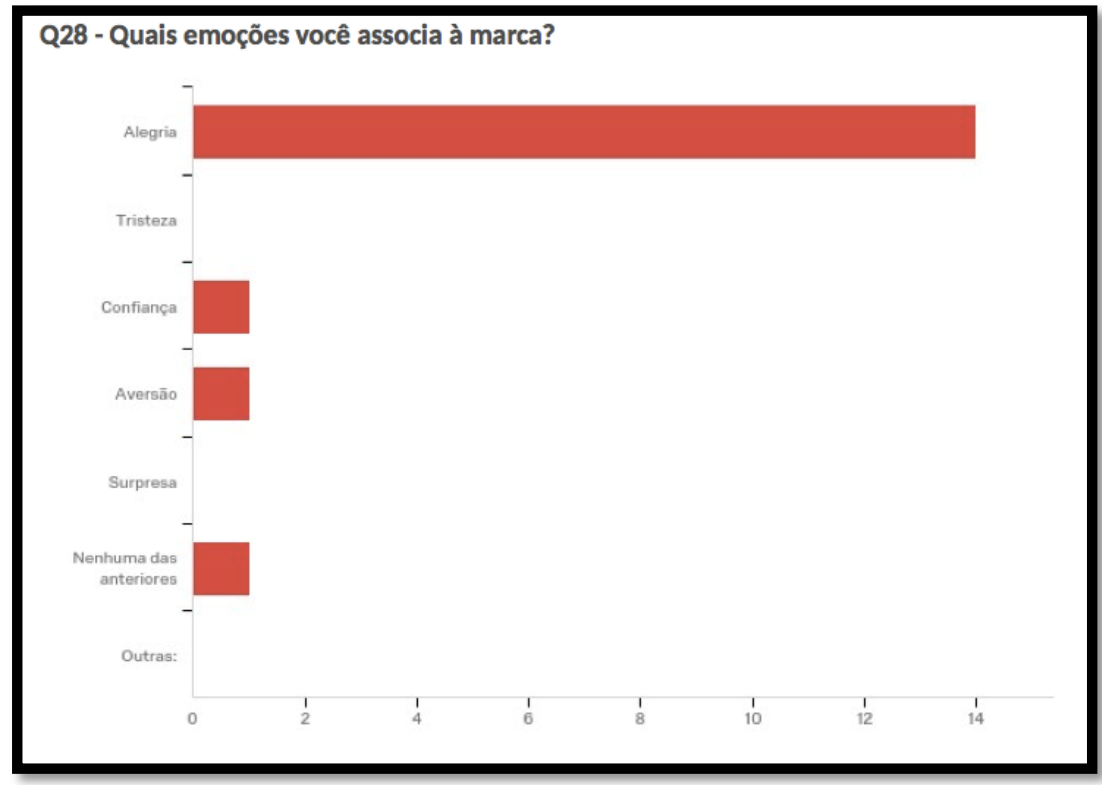

Gráfico 28: Quais emoções você associa à marca? 
O estilo musical que mais associam à Farm é o "MPB", representando $64,71 \%$ da amostra. O hip hop foi escolhido por $11,76 \%$ dos entrevistados e o funk por 5,88\%, conforme o gráfico 29 . Nem o sertanejo e nem o rock foram associados pelos respondentes. A opção "nenhuma das anteriores" foi escolhida por $17,65 \%$ dos entrevistados.

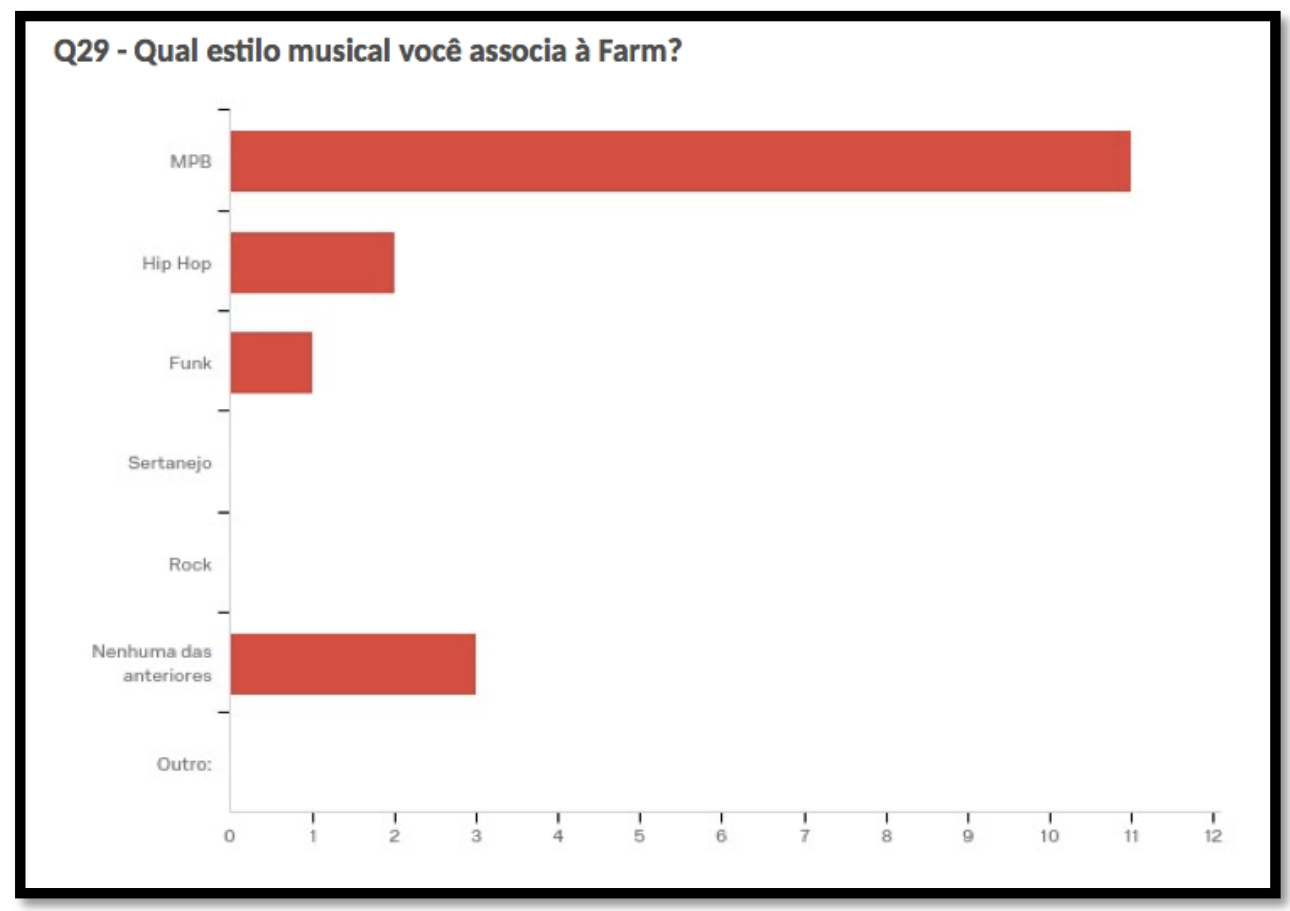

Gráfico 29: Qual estilo musical você associa à Farm?

Com quase $95 \%$ das escolhas, a opção que mais se aproxima da imagem que possuem de um consumidor típico da Farm, é de "meninas universitárias moradoras da zona sul carioca", de acordo com o gráfico abaixo. As opções "mulheres cariocas acima de 30 anos" e "meninas que moram fora do Rio de Janeiro" não foram escolhidas pelos não consumidores. Já 6,25\% dos entrevistados associam todas as opções citadas anteriormente à marca. 
Q30 - Qual das opções abaixo mais se aproxima da imagem que você tem de um consumidor típico da Farm?

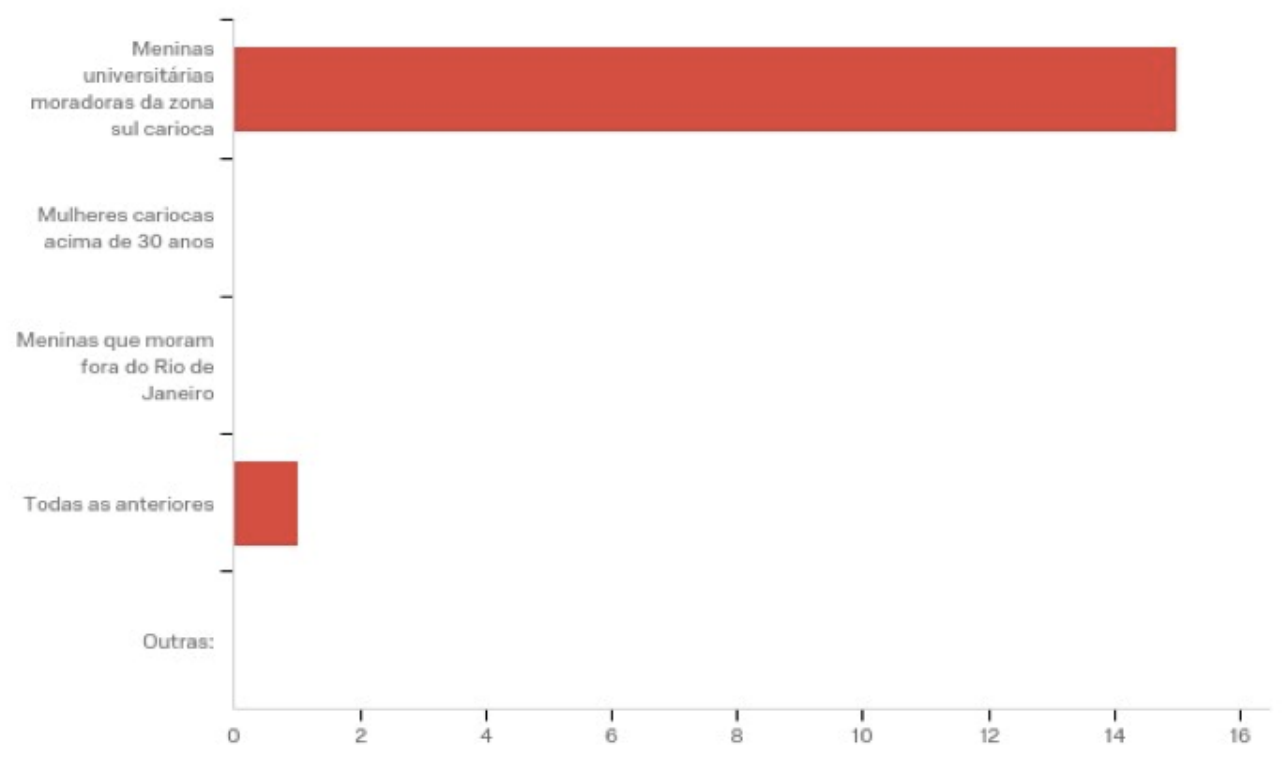

Gráfico 30: Qual das opções abaixo mais se aproxima da imagem que você tem de um consumidor típico da Farm?

Por fim, quase 95\% dos respondentes disseram achar que a Farm não dialoga com eles, conforme o gráfico 31 :

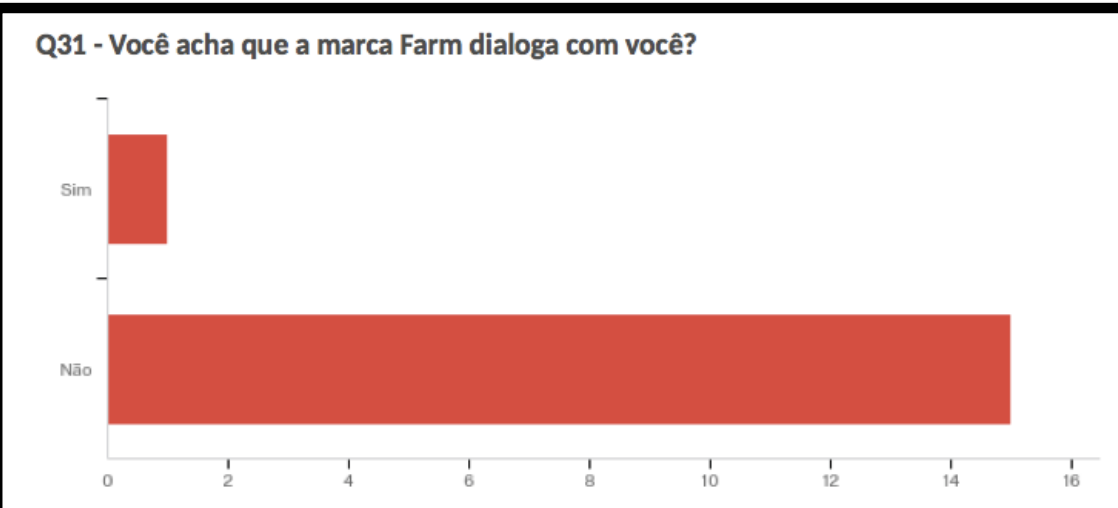

Gráfico 31: Você acha que a marca Farm dialoga com você? 


\section{Conclusões e recomendações para novos estudos}

Este capítulo resume as principais contribuições produzidas ao tema em estudo. Sendo assim, este trabalho investigou como é a percepção de imagem da Farm pelas seus clientes e não-clientes.

O estudo de literatura foi feito através de artigos, livros e estudos acadêmicos, tendo em foco abordar a análise da marca com seu estereótipo/público-alvo e principalmente pelos que não são o público-alvo da loja. Esta análise foi realizada através de um questionário de forma quantitativa, com 31 perguntas e uma amostra de 101 pessoas.

Primeiramente, foi identificado o perfil do entrevistado, onde foi revelado que a maioria é do sexo feminino, jovem (entre 18 e 35 anos), estudante ou estagiário cursando ainda o Ensino Superior, morador da Zona Sul do Rio de Janeiro e das classes A e B. Posteriormente, foi constatado que $84,16 \%$ dos entrevistados já frequentaram alguma loja da Farm e que sua maior parte frequenta a loja a cada seis meses.

Pode-se concluir que as vitrines das lojas e liquidação são fatores motivantes para as consumiras entrarem nas lojas, que geralmente estão à procura de roupas para o uso cotidiano.

Para Aaker (1998), as associações feitas à marca são caracterizadas quando qualquer coisa ligada à ela vem na mente. Sendo assim podemos dizer que os consumidores da Farm associam a marca à itens coloridos, à cidade do Rio de Janeiro, a passeios ao ar livre, sair para almoçar e fazer picnic, à alegria e à meninas universitárias moradoras da zona sul carioca.

Já os não consumidores também associam à marca itens muito coloridos, a cidade do Rio de Janeiro, passeios ao ar livre, a emoção de alegria e meninas universitárias moradoras da zona sul carioca.

Conclui-se assim que a percepção de imagem que os consumidores e os não consumidores possuem da Farm é a mesma e é exatamente o que ela quer passar e o público que ela quer atingir: pessoas que gostam de roupas estampadas, despojadas; meninas jovens, cariocas moradas da zona sul, estudantes, que gostam de praia, estilosas; pessoas alegres que adoram estampa coloridas e conforto na hora de se vestir. 
Os não clientes da marca são desencorajados a entrarem na Farm, na sua maior parte pelos produtos e design das roupas oferecidos pela marca. Conforme citado anteriormente por Aaker (1998), a qualidade percebida é definida como o conhecimento que o consumidor tem da qualidade geral de um produto em relação a alternativas. Este é um dos fatores determinantes para os clientes da marca de desmotivarem a entrarem nas lojas, onde citam a baixa qualidade e modelagem dos produtos que compram, além do insatisfatório atendimento por parte das vendedoras, que muitas vezes são antipáticas, lentas e não-prestativas.

Sendo assim, é possível concluir que isto impacta negativamente a marca, pois tanto os não consumidores, quanto os consumidores da Farm, podem fazer um marketing boca-a-boca sobre o que eles não gostam na marca, e outras pessoas que podem não conhecer a mesma, acabam não entrando na loja, e consequentemente, não consumindo.

Para estudos futuros, seria recomendável analisar a revisão de literatura através de outros autores e modelos, para possuir informações diferentes.

Outra sugestão seria realizar um questionário com uma amostra maior, para os resultados serem mais próximos a realidade.

E por fim, para os gestores da Farm, serviria de objeto de estudo para melhorar seu posicionamento e buscar melhorar sua percepção de imagem perante os consumidores e não consumidores da marca. 


\section{Referência Bibliográficas}

ABC CONSULTORES, Relacionamento que encanta e fideliza clientes: Conheça o caso Farm. Disponível em: http://www.abcconsultores.com.br/2010/10/relacionamento-que-encanta-efideliza-clientes-conheca-o-caso-farm/. Acesso em: 11 de dezembro de 2016.

AAKER, DAVID A., Construindo Marcas Fortes. 1. ed. Editora Bookman, 2007.

AAKER, DAVID A., Marcas Brand Equity: Gerenciando o Valor da Marca. 2. ed. São Paulo: Negócio Editora, 1998.

ESTILO, Conheça a moda colorida e estampada da grife Farm. Disponível em: <http://estilo.abril.com.br/moda/conheca-a-moda-colorida-e-estampada-dagrife-farm/>. Acesso em: 26 de novembro de 2016.

FARM, A Farm. Disponível em: <http://www.farmrio.com.br/br/a-farm>. Acesso em: 12 de dezembro de 2016.

FARM, Apresentação fornecida pela empresa. Acesso em: 13 de outubro de 2017.

FARM, Página do Facebook da marca: Adoro Farm. Disponível em: < https://www.facebook.com/adorofarm/>. Acesso em: 13 de outubro de 2017.

FARM, 0 Grupo de Moda Soma. Disponível em: <http://www.farmrio.com.br/br/institucional-grupo-somas. Acesso em: $11 \mathrm{de}$ dezembro de 2016.

HELENA, L. Kátia Barros, a estilista preferida das garotas cariocas. O Globo, 15 de dezembro de 2013. Disponível em: <http://oglobo.globo.com/rio/katiabarros-estilista-preferida-das-garotas-cariocas-11072963>. Acesso em: 11 de dezembro de 2016.

MALHOTRA, NARESH K., Introdução à Pesquisa de Marketing. Editora Pearson Prentice Hall, 2006.

MCCRACKEN, GRANT D., Cultura e Consumo. 1 ed. Rio de Janeiro, Mauad, 2003.

O NEGÓCIO DO VAREJO. Para Farm, fusão com Animale foi fundamental. Disponível em: <http://onegociodovarejo.com.br/para-farm-fusao-com-animalefoi-fundamental/>. Acesso em: 11 de dezembro de 2016.

PEREIRA, C. E BARROS, C., Cariocas não gostam de dias nublados: 
comunicação, consumo e lifestyle no discursos da FARM. Acesso em: 01 de novembro de 2017.

PINHO, J. B., O Poder das Marcas. 7. ed. São Paulo: Summus Editoria, 1996.

ROGAR, S. Borogodó carioca: o fenômeno da Farm. Vogue, 21 de novembro de 2015. Disponível em: <http://vogue.globo.com/moda/modanews/noticia/2015/11/borogodo-carioca-o-fenomeno-da-farm.html>. Acesso em: 11 de dezembro de 2016.

SCHMITT, BERND, Experiential Marketing: How to get customers to sense, feel, think, act and relate to your company and brands. The Free Press, 1999.

SOLOMON, MICHAEL R., O comportamento do consumidor: comprando, possuindo e sendo. 9 ed. Porto Alegre: Bookman, 2011.

TEAMRP, 0 Início da Loja de moda jovem FARM. Disponível em: $<$ https://teamrp.wordpress.com/2010/06/03/o-inicio-da-loja-de-moda-jovemfarm/>. Acesso em: 11 de dezembro de 2016.

VOGUE BRASIL, Polêmica: CEO da Abercrombie não quer consumidores gordos, diz autor. Disponível em: <http://vogue.globo.com/moda/modanews/noticia/2013/05/polemica-ceo-da-abercrombie-nao-quer-consumidoresgordos-diz-autor.html>. Acesso em: 26 de novembro de 2016.

ZIKMUND, WILLIAM G. E BABIN, BARRY J., Princípios da Pesquisa de Marketing. 2 ed. São Paulo: Cengage Learning, 2011. 


\section{Apêndice A}

Questionário aplicado aos consumidores e não consumidores da Farm

Essa pesquisa será utilizada apenas para fins acadêmicos da PUC-Rio. Tem como objetivo entender o comportamento dos consumidores e dos não consumidores da loja Farm.

Q1. Qual seu gênero?

( ) Feminino

( ) Masculino

Q2. Qual sua faixa etária?

( ) 17 anos ou menos

( ) 18 a 25 anos

( ) 26 a 35 anos

( ) 36 a 45 anos

( ) 46 a 55 anos

( ) 56 ou mais

Q3. Qual a sua ocupação/profissão?

\section{Q4. Onde você mora?}

( ) Zona Sul do Rio de Janeiro

( ) Zona Norte do Rio de Janeiro

( ) Zona Oeste do Rio de Janeiro

( ) Fora do Rio de Janeiro 
Q5. Qual sua faixa de renda familiar?

( ) Superior a $\mathrm{R} \$ 11.262,00$

( ) Entre $R \$ 11.261,00$ e $R \$ 8.641,00$

( ) Entre $R \$ 8.640,00$ e $R \$ 2.005,00$

( ) Entre $R \$ 2.004,00$ e $R \$ 1.255,00$

( ) Igual ou inferior a $R \$ 1.254,00$

Q6. Qual seu grau de escolaridade?

( ) Ensino Fundamental Incompleto

( ) Ensino Fundamental Completo

( ) Ensino Médio Incompleto

( ) Ensino Médio Completo

( ) Ensino Superior Incompleto

( ) Ensino Supeior Completo

( ) Pós Graduação Incompleta

( ) Pós Graduação Completa

( ) Mestrado

( ) Doutorado

( ) Pós Doutorado

( ) Outro:

Q7. Você já freqüentou alguma loja da marca Farm?

( ) $\mathrm{Sim}$

( ) Não

Caso resposta for sim:

Q8. Com qual freqüência você vai a uma loja da marca?

( ) Uma vez ao ano

( ) A cada seis meses

( ) Uma vez a cada dois meses 

( ) Todo mês
( ) Toda semana
( ) Outro:

Q9. O que te motiva a entrar na loja?

( ) A vitrine

( ) Liquidação

( ) Curiosidade em saber se tem peças novas

( ) Estou à procura de uma peça específica

( ) Outro:

( ) Todas as anteriores

Q10. Quando você compra na Farm, você geralmente quer...

( ) Uma roupa para uma ocasião especial

( ) Uma roupa para uso cotidiano

( ) Um item específico que só encontro lá. Qual?

( ) Um presente. Para quem? Descreva o tipo de relacionamento

( ) Outro:

Q11. Quais elementos você mais gosta nas lojas da Farm?

( ) Decoração

( ) Música

( ) Estampa

( ) Produtos

( ) Aroma

( ) Atendimento

( ) Nenhuma das anteriores

( ) Outros:

Q12. Quais elementos você não gosta nas lojas da Farm?
( ) Decoração
( ) Música 

( ) Estampa
( ) Produtos
( ) Aroma
( ) Atendimento
( ) Nenhuma das anteriores
( ) Outros:

Q13. O que você considera que seja o diferencial da marca?
( ) Design das roupas
( ) Bom preço
( ) Experiência nas lojas
( ) Ações promocionais
( ) Nenhuma das anteriores
( ) Outro:

Q14. Quais cores você associa à Farm?
( ) Amarelo
( ) Vermelho
( ) Verde
( ) Azul
( ) Laranja
( ) Vermelho
( ) Todas as anteriores
( ) Outras:

Q15. Quais cidades você associa à marca?
( ) Rio de Janeiro
( ) Salvador
( ) Porto Alegre
( ) Nova York
( ) Sidney
( ) Nenhuma das anteriores
( ) Outras: 
Q16. Quais situações você associa à Farm?

( ) Passear ao ar livre

( ) Passear no shopping

( ) Trabalhar

( ) Ir à faculdade

( ) Fazer um picnic

( ) Sair para almoçar

( ) Todas as anteriores

( ) Outras:

Q17. Quais emoções você associa à marca?

( ) Alegria

( ) Tristeza

( ) Confiança

( ) Aversão

( ) Surpresa

( ) Nenhuma das anteriores

( ) Outras:

Q18. Qual estilo musical você associa à Farm?
( ) MPB
( ) Hip Hop
( ) Funk
( ) Sertanejo
( ) Rock
( ) Nenhuma das anteriores
( ) Outro:

Q19. Qual das opções abaixo mais se aproxima da imagem que você tem de um consumidor típico da Farm?
( ) Meninas universitárias moradoras da zona sul carioca
( ) Mulheres cariocas acima de 30 anos
( ) Meninas que moram fora do Rio de Janeiro 
( ) Todas as anteriores

( ) Outros:

Q20. Existe algum aspect que te desencoraja a comprar na Farm? Explique.

Q21. Você acha que a marca Farm dialoga com você?

( ) $\operatorname{Sim}$

( ) Não

Caso resposta for não:

Q8. Quais aspectos te desencorajam a entrar na loja da Farm?
( ) A vitrine
( ) Design das roupas
( ) Atendimento
( ) Produtos
( ) Todas as anteriores
( ) Outro:

Q9. Quais elementos você mais gosta nas lojas da Farm?
( ) Decoração
( ) Música
( ) Estampa
( ) Produtos
( ) Aroma
( ) Atendimento
( ) Nenhuma das anteriores
( ) Outros:

Q10. Quais elementos você não gosta nas lojas da Farm?

( ) Decoração 

( ) Música
( ) Estampa
( ) Produtos
( ) Aroma
( ) Atendimento
( ) Nenhuma das anteriores
( ) Outros:

Q11. Quais cores você associa à Farm?
( ) Amarelo
( ) Vermelho
( ) Verde
( ) Azul
( ) Laranja
( ) Vermelho
( ) Todas as anteriores
( ) Outras:

Q12. Quais cidades você associa à marca?
( ) Rio de Janeiro
( ) Salvador
( ) Porto Alegre
( ) Nova York
( ) Sidney
( ) Nenhuma das anteriores
( ) Outras:

Q13. Quais situações você associa à Farm?
( ) Passear ao ar livre
( ) Passear no shopping
( ) Trabalhar
( ) Ir à faculdade
( ) Fazer um picnic
( ) Sair para almoçar 
( ) Todas as anteriores

( ) Outras:

Q14. Quais emoções você associa à marca?
( ) Alegria
( ) Tristeza
( ) Confiança
( ) Aversão
( ) Surpresa
( ) Nenhuma das anteriores
( ) Outras:

Q15. Qual estilo musical você associa à Farm?
( ) MPB
( ) Hip Hop
( ) Funk
( ) Sertanejo
( ) Rock
( ) Nenhuma das anteriores
( ) Outro:

Q16. Qual das opções abaixo mais se aproxima da imagem que você tem de um consumidor típico da Farm?
( ) Meninas universitárias moradoras da zona sul carioca
( ) Mulheres cariocas acima de 30 anos
( ) Meninas que moram fora do Rio de Janeiro
( ) Todas as anteriores
( ) Outros:

Q17. Você acha que a marca Farm dialoga com você?
( ) Sim
( ) Não 


\section{Apêndice B}

\section{Q3 - Qual a sua ocupação/profissão?}

Qual a sua ocupação/profissão?

\section{Advogado}

Empreendedora

Administradora

Estudante de engenharia

Estudante

Recepcionista

Estagiaria de administracao

Estudante de arquitetura

Assistente administrativa

Empreendedora

Estudante de jornalismo

Psicologa

Estudante

Professora de educacao fisica

Estudante de design

\begin{tabular}{|l|}
\hline Empreendedora \\
\hline Estudante de asministracao \\
\hline Publicitario \\
\hline Aposentada \\
\hline Estudante \\
\hline Administradora \\
\hline Publicitaria \\
\hline Estudante \\
\hline Estudante \\
\hline Administrador \\
\hline Designer \\
\hline Estudante \\
\hline Medica \\
\hline
\end{tabular}


Estudante

Aposentada

Professora de educacao fisica

Estudante de arquitetura

Estagiaria de administracao

Economista

Engenheira

Designer

Asministracao - estagiaria

Arquiteta

Professora de portugues

Estudante

Arquiteta

Estagiária

Estudante

Estudante

Estudante de arquitetura

Estudante de administracao

Estudante

Estilista

\begin{tabular}{|l|}
\hline Estudante \\
\hline Estudante - estagiário \\
\hline Estudante \\
\hline Estudante \\
\hline Estagiario \\
\hline Estudante \\
\hline estudante \\
\hline Estudante \\
\hline Estudante + assistente contabil \\
\hline Secrataria \\
\hline Assistente de estilo \\
\hline Estudante \\
\hline
\end{tabular}


Estudante

Estudante de administraçao e estagiária

Estudante de administração

Estudante

Estagiária de RH

Trainee de Gerenciamento de Recursos

estudante

Estudante

estudante

Estudante

Estudante

Estudante

Estudante/estagiário

Supervisora de marketing

Estudante

Estudante

Estudante

Analista Jr

Economista

Estudante de administração

\begin{tabular}{|l}
\hline Empreendedor \\
\hline Estudante \\
\hline Estagiária \\
\hline Estagio \\
\hline Estudante \\
\hline Estudante \\
\hline Design d interiores \\
\hline Estudante \\
\hline Estudante \\
\hline EStudante \\
\hline Estudante de direito /atriz \\
\hline Psicologa \\
\hline
\end{tabular}

Secretária

Estudante

Economista

Estudante

Publicitaria

Administradora

Estudante

Estudante

\section{Gráfico 3: Qual sua ocupação/profissão?}




\section{Apêndice C}

\section{Q20 - Existe algum aspecto que te desencoraja a comprar na Farm? Explique.}

Existe algum aspecto que te desencoraja a comprar na Farm? Explique.

Atendimento insatisfatorio

Qualidade da roupa e algumas que sao tamanho grande parecem pequenas

Nenhum

Atendimento ruim, com ma vontade e lentas

Roupas com caimento ruim, pequenas e que encolhem quando lavam

Modelagem das roupas é pequena

Roupas com modelagens pequenas, o tamanho $G$ parece $P$. $E$ algumas pecas vestem mal tambem, nao tem um caimento bom no corpo

Modelagem das roupas, algumas encolhem apos lavagem e nao tem caimento born para pessoas tamanho $\mathrm{G}$

Algumas estampas sao feias $\mathrm{e}$ algumas pecas encolhem quando lavam

Algurnas roupas encolhem e vestem mal

Qualidade das roupas, as vezes elas encolhem

Ja tive mais de uma experiencia com vendedoras muito lentas

Nao

Nenhum

Nenhum

Nenhum

Nenhum

Ja tive experiencias de atendimentos ruins

Atendimento ruim, onde as vendedoras nao sao simpaticas e nao trazem todas as roupas que voce escolheu porque esquecem

Atendimento ruim

Nenhum

Modelagens de algumas coisas sao ruins (vestem mal)

Atendimento ruim

Experiencias insatisfatorias de atendimento

Ja tive experiencias insatisfatorias

Modelagem de algumas pecas sao ruins (caimento da roupa), estampas exageradas e ja tive experiencia de atendimento ruim

Atendimento insatisfatorio 
Caimento de algumas roupas e estampas chamativas

Modelagem ruim, algurnas roupas nao vestem bem

Atendimento ruim

Nao tem roupa masculina

Modelagem e qualidade um pouco ruins.

Atendimento

Baixa qualidade e preco cafo

Algumas roupas estranhas e com modelagens ruins e estampas tao exageradas que ficam feias.

Preço

Modelagem das pecas

Sou homem.

Preço exacerbado em comparação a qualidade das peças

Nao

Modelagem mt pequena

Modelagem pequena

Preço e a qualidade das roupas esta ruim (costura e tecido) a

Muitas estampas as vezes

Atendimento ruim e preço alto

Não

Muito informal

Preco

Atendimento/ vendedoras

todas as polêmicas relacionadas a racismo e preconceito contra religiōes de matriz africana

Qualidade das roupas e variedade das estampas

O preço e a qualidade. O preço cobrado por uma peça não condiz corn a qualidade dos tecidos que eles usam pra produzir. É um preço muito elevado pro que se é vendido.

Tamanho das roupas. As modelagens sao sempre pequenas

Preço

A vibe "ostentaçao" disfarçada

Preço

Atendimento péssimo pro preço altíssimo.

Preço muito alto

Muito estimulo visual nas lojas

Preço elevado.

Sim, quando a roupa é ousada demais

Não

Alto preço

Um chinelo custar 200 reais

N

Falta de qualidade de algumas peças por altos preços

Alguns produtos de ma qualidade

Preço

Tamanho das roupas, raramente encontro peças pra quem está fora dos padrões (magro)

Preço

Preços

atendimento nas lojas confuso

Qualidade e modelagem

Vendedoras chatas e metidas e, hoje em dia, preço, porque costumam ser preços altos para roupas de uso cotidiano e não para eventos

Preço

Preço. Acredito que os produtos não valem o preço que são.

as estampas excessivas

Gráfico 11: Existe algum aspecto que te desencoraja a comprar na Farm? Explique. 